\title{
ARTICLES
}

\section{HEIGHTENED SCRUTINY OF THE FOURTH BRANCH: SEPARATION OF POWERS AND THE REQUIREMENT OF ADEQUATE REASONS FOR AGENCY DECISIONS}

\author{
SIDNEY A. SHAPIRO* \\ AND RICHARD E. LEVY**
}

Judicial review of administrative action is an inexact science. Professors Shapiro and Levy argue that this is partially because review of administrative actions is an unexplained science. In this article, they examine how the evolution of judicial review of agencies has reflected changing political values in American government. They argue that courts now require agencies to provide adequate reasons for their actions, and, by tracing the development of that requirement, they demonstrate that the courts have not fully explained the signiflcance of or doctrinal basis for this model of review. The article concludes that the adequate reasons requirement is best understood, and applied, as a derivation of the separation of powers doctrine.

I. Political Values and Judicial Review ................. 390

A. Liberal Values in American Government ............ 391

B. Progressive Values in American Government.......... 392

C. Value Conflict and the Problem of Judicial Review ..... 394

II. The Evolution of Judicial Review and the Accommodation of Political Values .............................. 396

A. The Structuralist Model ....................... 398

1. The Evolution of Structuralism ............ 398

* Professor of Law, University of Kansas. B.S., 1970, J.D., 1973, University of Pennsylvania.

** Associate Professor of Law, University of Kansas. B.A., 1978, M.A., 1980, University of Kansas; J.D., 1984, University of Chicago.

The authors would like to thank Walter Gellhorn, Robert Glicksman, Robert Jerry, Phillip Kissam, William Lawrence, Ronald Levin, Kathleen Levy, Jonathon Macey, Richard Pierce, Richard Posner, Peter Schanck, and Cass Sunstein for helpful comments on an earlier draft; and to thank Wayne Smith and Veronica Jongenellan, Class of 1987, and Cheryl Waldron, Class of 1988, for their research assistance. The authors gratefully acknowledge the support of the University of Kansas General Research Fund which made this study possible. 
2. The Failure of Structuralism ............... 403

B. The Proceduralist Model ........................ 404

1. The Evolution of Proceduralism ............... 405

2. The Failure of Proceduralism ................. 407

C. The Rationalist Model ........................ 410

1. The Evolution of Rationalism .................. 410

2. The Prospects of Rationalism ................. 412

III. The Evolution of the Reasons Requirement and the Models of Judicial Review .............................. 413

A. Reasons and Structuralism..................... 414

B. Reasons and Proceduralism .................... 416

1. The Proceduralist Understanding ............... 417

2. The "Hard Look" Gloss ........................ 419

C. Reasons and Rationalism ...................... 422

IV. Separation of Powers, Rationalism, and the Reasons Requirement............................... 425

A. Separation of Powers and the History of the Reasons

Requirement ............................... 425

B. Rationalism and Liberal Values .................. 428

1. Substantive Review and Liberal Values............ 429

2. The Availability of Review ................... 430

C. Rationalism and Progressive Values............... 432

1. Substantive Due Process ..................... 433

2. Rationalism and Procedural Inefficiency .......... 435

3. Rationalism and Expertise ................... 436

V. Conclusion ..................................... 440

Appendix................................ 440

In recent years, the requirement that administrative agencies provide adequate reasons for their decisions has come to play a central role in judicial review of agency decisions. While the increasing importance of this requirement has been recognized, no systematic study of its history and doctrinal basis has been undertaken. This article proposes that the requirement is best understood as a form of heightened scrutiny of the rationale of agency decisions and that the doctrine of separation of powers requires such scrutiny because of the unique position of administrative agencies in terms of the constitutional structure of government. This separation of powers conception of the reasons requirement derives from an analysis of political values underlying administrative law, the evolution of various models of judicial review, and the history of the reasons requirement itself. 
Part I of the article considers the political values underlying our governmental structure and describes the apparent conflict between two competing sets of values. "Liberal" values restrict government action in order to preserve individual freedoms and are reflected in the Constitution through principles such as representative government, separation of powers, and due process. "Progressive" values promote government action in order to relieve social problems, and are implemented through delegation of legislative and judicial powers to unelected administrators functioning outside of the political and constitutional limitations originally established for the exercise of those powers. Thus, administrative law jurisprudence is faced with the difficult task of accommodating two sets of conflicting values.

Part II of the article examines the Supreme Court's efforts to accommodate liberal and progressive values through its articulation of the scope of judicial review of agency decisions. This examination identifies three distinct models of review reflecting the Court's evolving jurisprudence-a "structuralist," a "proceduralist" and a "rationalist" model. We argue that the structuralist and proceduralist models have failed to accommodate progressive and liberal values both as a theoretical and practical matter. These models could not explain how liberal values had been preserved in the face of acceptance of progressive programs; nor could they provide meaningful protection for affected parties without unduly impairing the admimistrative process. We suggest that as a result the Court is turning to the rationalist model of judicial review, which has as its central feature the requirement that agencies articulate adequate reasons for their decisions. However, the Court has not fully explained the significance of this requirement, or the doctrinal basis of the rationalist model.

Part III of the article locates that doctrinal basis by tracing the heretofore unexplored origin and development of the adequate reasons requirement. This history reveals that the requirement originally had a separation of powers dimension which was later obscured by the influence of the proceduralist model. This separation of powers dimension provides the basis for a more complete articulation of the rationalist model of judicial review.

Part IV of the article demonstrates that the requirement of adequate reasons is best understood as a product of the separation of powers doctrine. This understanding not only reflects the history of the requirement, but also enables the rationalist model to accommodate liberal and progressive values. At the theoretical level, the rationalist model explains how structural safeguards are preserved so as to protect liberal values. At the practical level, the rationalist model provides a meaning- 
ful check on administrative action without unduly impairing the implementation of progressive programs by administrative agencies.

Finally, an Appendix to the article describes a survey of recent federal courts of appeals decisions reviewing agency action, and contains a table summarizing the results of the survey. These results demonstrate the current significance of the reasons requirement, and the emergence of the rationalist model of juclicial review.

\section{Political Values and Judicial Review}

Over the years, the Supreme Court has struggled to accommodate the two strains of political values underlying modern American government. There is a general social consensus that government ought to adhere to such "liberal" values as representative government, separation of powers, and due process. ${ }^{1}$ There is less consensus about the extent to which government ought to implement "progressive" values by accepting responsibility for social and economic improvements; those values, however, retain much strength. ${ }^{2}$ These two strains of political values are in potential conflict, because the governmental institutions which implement progressive values do not operate in a manner that is entirely consistent with the constitutional franework designed to implement hiberal values. ${ }^{3}$

Judicial review of agency actions reflects this conflict because each set of political values requires a different form of judicial review.

1. See R. Dahl, Democracy in the United States: Promise and Performance 357 (1972). See generally L. Hartz, The Liberal Tradition in America: AN INTERPRETation of american Political Thought Since the Revolution (1955).

2. Rabin, Federal Regulation in Historical Perspective, 38 Stan. L. REv. 1189, 1325 (1986) (A. "half-century after the New Deal-a century after the birth of the regulatory system-... while a broadranging commitment to government intervention seems a continuing legacy ... no consensus exists on the appropriate scope of federal regulatory activities.").

3. Opponents of government activism rely on this inconsistency to challenge the modern regulatory state. As Professor Samuel Huntington notes:

The widespread consensus on liberal-democratic values provides the basis for challenging the legitimacy of American political practices and the authority of American political institutions. The consensus constitutes an external standard for judging institutions, and often for judging them harshly. Political institutions and practices never measure up to the ideals and values of the [liberal] Creed and hence can be seen as illegitimate. ... Intense [public] awareness of this gap becomes a driving force for reformation of the political system. These efforts to bring political reality into accord with political principle are the major source of political change in America.

S. Huntington, American Politics: The Promise of Disharmony 32 (1981). 
TABLE 1

Political Values

Liberal

Progressive
Basis

Separation of powers \& due process

Practical necessity, expertise \& efficiency
Implication for

Judicial Review

Requires meaningful review

Requires deferential review

Liberalism requires meaningful judicial review, while progressivism requires judicial review that is deferential. Thus, the problem for any theory of judicial review is how both sets of inherent American political values can be accommodated. ${ }^{4}$

\section{A. Liberal Values in American Government.}

The principles of American democracy were influenced by the "liberal" philosophical and political movements that dominated England and Europe in the century before this country was founded. ${ }^{5}$ While the coercive ordering of behavior by the state restricts individual liberty, liberal thinkers agreed with Hobbes that the absence of a state is a far more devastating blow to freedom. ${ }^{6}$ They therefore accepted that a government was both legitimate and desirable, but that it must be a government organized by individual consent and of determinate political limits. ${ }^{7}$

In the United States, the constitutional structure of government and the establishment of individual rights reflect these hiberal values. Structural protections include specification of the powers of the government in the Constitution ${ }^{8}$ and a division of governmental authority into a legislative, executive, and judicial branch, each of which exercises certain

4. While some have argued that the problem of administrative discretion requires rejection of government regulation altogether, see, e.g., F. HAYEK, THE CONSTITUTION OF LIBERTY 212-15 (1960); F. HAYEK, THE RoAd TO SERFDOM 10-23 (1944), the country is now so committed to the progressive program, which requires at least some administrative agencies for its implementation, that this alternative cannot be seriously considered. See infra note 13.

5. See J. Pennock, Liberal Democracy: Its Merits and Prospects 9-16 (1950). See generally L. HARTZ, supra note 1, at 3-27.

6. T. Hobbes, Leviathan 80-84, 109-13 (M. Oakeshott ed. 1946); see also H. Kelsen, PURE THEORY OF LAW 37-38 (M. Knight trans. 2d ed. 1967) (collective security requires state monopoly on use of force). See generally R. EPSTEIN, TAkIngs: Private Property AND THE POWER OF EMINENT DOMAIN 7-18 (1985) (discussing impact of Hobbes and Locke on constitutional structure).

7. A. Levine, Liberal Democracy: A Critique of its Theory 22-23 (1981).

8. See U.S. CONST. amend. X; infra notes 36-39 and accompanying text (discussing Supreme Court interpretation of these constraints). 
checks over the others. 9 Individual rights, enumerated in the Bill of Rights, include a right that deprivations of liberty and property could proceed only after the operation of due process of law. ${ }^{10}$

There have always been important differences within the liberal tradition concerning the function of government. Some Liberals emphasize the Lockean view that while the existence of government is necessitated by the human condition, its only proper function is the facilitation of individual initiative. ${ }^{11}$ Other Liberals emphasize the republican tradition that government is responsible for promoting the general welfare. ${ }^{12} \mathrm{With}$ the advent of the progressive era, those favoring governmental activism prevailed. ${ }^{13}$ Progressive government, however, involves activism beyond that envisioned by the Framers and is implemented in a manner that appears to threaten important liberal principles.

\section{B. Progressive Values in American Government.}

The progressive movenent in American politics in large measure was a reaction to the social and political conditions produced by the laissez-faire political environment of the last part of the nimeteenth century. ${ }^{14}$ The Progressives believed that government had been corrupted by the concentration of political power in large corporations, trusts and political bosses; that industry should be regulated and workers protected; that poverty and old-age hardship should be relieved; and that natural resources should be protected. ${ }^{15}$

9. See The Federalist No. 81, at 347 (A. Hamilton) (C. Beard ed. 1948); see also ThE Federalist No. 47, at 211 (J. Madison) (C. Beard ed. 1948); The Federalist No. 48, at 217 (J. Madison) (C. Beard ed. 1948); The Federalist No. 51, at 224-25 (J. Madison) (C. Beard ed. 1948). For a disoussion of the Supreme Court's interpretation of the separation of powers constraint, see infra notes 40-51 and accompanying text.

10. U.S. CONST, amend. V; see infra notes $72-93$ and accompanying text (discussing procedural safeguards required by due process and statutes).

11. A. Levine, supra note 7, at 17; see R. EPSTEIN, supra note 6, at 7-18.

12. See Sunstein, Interest Groups in American Public Law, 38 STAN. L. REV. 29, 31 (1985).

13. Rabin, supra note 2, at 1325 ("[A] broadranging commitment to government intervention seems a continuing legacy of the New Deal ... ."); $c f$. J. RoBERTSON, AMERICAN MYTH, AMERICAN REALITY 297 (1980) ("[Americans] have, in our common experience, all become progressives ...."). Despite the rhetoric of the Reagan administration, the 1980s have not seen a significant dismantling of the progressive regulatory framework. See Lowi, Two Roads to Serfdom: Liberalism, Conservatism and Administrative Power, 36 AM. U.L. REv. 295, 311-12 (1987).

14. See generally R. Hofstadter, The Age of Reform (1955). Until the last part of the nineteenth century, government undertook few regulatory functions; almost all of those concerned the promotion of economic development by subsidizing business or the purchase of public goods. See S. Breyer \& R. Stewart, Administrative LaW and Regulatory Policy 24-26 (2d ed. 1985).

15. R. Cushman, The Independent Regulatory Commissions $37-40$ (1941); R. Wiebe, THE SEARCH FOR ORDER 1877-1920, at 167-95 (1967). 
Progressive support for regulation was closely allied with a movement towards scientific rationalism, which emphasized that human and organizational behavior was the product of relationships that can rationally be deduced and described by empirical and objective inquiry. ${ }^{16}$ As a corollary, the Progressives believed that most social problems could be solved by expertly trained scientists or by persons familiar with the scientific disciplines. ${ }^{17}$ Progressive interest in scientific expertise was also the product of dissatisfaction with the corruption and inefficiency of nineteenth century government. Progressive political writers championed such expertise as a dispassionate and impartial methodology that could insulate government administration from an undesirable political environment. 18

Althougl the development of administrative government may have been a pragmatic response to the social needs of the time, ${ }^{19}$ its form certainly reflected progressive beliefs. The adoption of a bureaucratic form of organization and the civil service system reflected the Progressives' interest in a more efficient and less political government. ${ }^{20}$ The creation of the independent agency facilitated the progressive goals of specialization, efficiency and insulation from the political forces that dominated legislatures and executive branches at both the state and federal level. ${ }^{21}$ Finally, the expansion of state and federal regulation refiected progressive beliefs that social problems could be solved by the bureaucratic ap-

16. E. Purcell, The Crisis of Democratic Theory: Scientific Naturalism \& the Problem of VAlue 5-12 (1973).

17. B. Ackerman \& W. Hassler, Clean Coal/Dirty AIR 4 (1981). Within the movement there was disagreement regarding the extent to which reliance should be placed on bureaucratic expertise, see J. Penick, Progressive Politics And Conservation 188-89 (1968), but even those who objected to bureaucracy as elitist recognized its growth as inevitable, and even desirable, in some contexts. Id. at 189.

18. See, e.g., Wilson, The Study of Administration, 2 Pol. SCI. Q. 197, 209 (1887) ("The field of administration is a field of business . . removed from the hurry and strife of politics . . . ."). President Wilson later expressed doubts about reliance on experts. See W. WILSON, CrossroadS of Freedom: The 1912 CAMPaign SPEeches of WoOdrow Wilson 83-84 (J. Davidson ed. 1956) ("What I fear, therefore, is a government of experts."). These doubts have recently been echoed. See infra notes 26-28 and accompanying text.

19. See W. Gellhorn, Federal Administrative Proceedings 5 (1941) (New agencies are created "not to satisfy in abstract governmental theory, but to cope with problems of recognized public concern."). See generally L. HARTZ, supra note 1, at 3-32 (Americans enjoy a liberal social consensus which reduces social conflict to narrow issues of economics and personality.)

20. During the Jacksonian era, federal agencies were subdivided into specialized bureaus with elaborate divisions of labor and chains of command. This move replaced the earlier organization which depended on generalists to administer government programs. W. NELSON, THE ROOTS OF AMERICAN BUREAUCRACY, 1830-1900, at 114, 116 (1982). This change was followed by formation of the federal civil service in the middle 1880s. Kaufman, Emerging Conflicts in the Doctrines of Public Administration, in The Polrtics of THE Federal Bureaucracy 76 (A. Altshuler ed. 1968).

21. M. Bernstein, Regulating Business by Independent Commission 26-30 (1955). 
plication of scientific expertise.22

The adoption of progressive government threatened liberal principles. It involved the delegation of decisionmaking authority to unelected administrators, gave those administrators the authority to use legislative and judicial powers that the Constitution appears to reserve for the Congress and the federal courts, and allowed the admimistrators to decide matters without the constraint of legal procedures traditionally used in the judicial system. ${ }^{23}$ Interests antagonistic to government regulation sought to invalidate progressive programs by challenging them before the Supreme Court as inconsistent with the Constitution and the liberal values that underlie it. Through these cases, the Court began to define the place and function of the administrative process in American government. That process of definition, which contmues today, requires the accommodation of liberal and progressive values.

\section{Value Conflict and the Problem of Judicial Review.}

The conflict between liberal and progressive values affects the legitimacy of administrative government. Because the authority of any institution rests ultimately on a popular belief in its legitimacy, ${ }^{24}$ political power must be held and exercised in accordance with a nation's laws, traditions, customs and values. ${ }^{25}$ Moreover, the affirmation of liberal values is all the more necessary because of growing doubts about the Progressives' assumption that social problems can be solved by the bureaucracy through application of scientific principles in a neutral fashion. ${ }^{26}$ In fact, administrative actions normally involve policy choices by

22. See $\mathrm{R}$. WIEBE, supra note 15 , at $150-63$ (application of principles of scientific management to the bureaucratic process is one innovation of the Progressive era). The states initiated this expansion by regulating railroads, grain elevators, and other monopolies, but the Supreme Court essentially halted that activity when it ruled that the states could not constitutionally regulate interstate commerce. Wabash, St. L. \& P. R.R. v. Illinois, 118 U.S. 557, 577 (1886) (holding that states could not regulate interstate railroad traffic within their borders). With state regulation blocked, Congress was influenced to create the Interstate Commerce Commission in 1887 to supervise competition in the railroad industry. Interstate Commerce Act of 1887, ch. 104, 24 Stat. 379 (codified as amended at 49 U.S.C. $\S \S 10101-11917$ (1982 \& Supp. III 1985)). Federal regulation of other industries, such as food and drugs, soon followed. See, e.g., Federal Meat Inspection Act, Pub. L. No. 59-242, 34 Stat. 1256, 1260 (1907) (codified as amended at 21 U.S.C. $\$ \S 601-695$ (1982 \& Supp. III 1985)); Pure Food and Drug Act, Pub. L. No. 59-384, 34 Stat. 768 (1906) (codified as amended at 21 U.S.C. $\S \S 301-392$ (1982 \& Supp. III 1985)). See generally J. LANDIS, The AdminISTRative Process (1938).

23. See R. Pierce, S. Shapiro \& P. Verkuil, Administrative Law and Process $\$ 2.5$ (1985).

24. M. Weber, The Theory of Social and Economic Organization 130-32 (T. Parsons ed. 1947).

25. J. Freedman, Crisis and Ligitimacy: The Administrative Process and AmeriCAN GOVERnMENT 10 (1978).

26. See supra notes 16-18 and accompanying text. 
bureaucrats who are subject to a variety of self-interested motivations and political pressures. ${ }^{27}$ When administrators respond to these influences, they often serve special interests of the industries they regulate rather than the purposes for which their agencies were created. ${ }^{28}$

In this country, judicial review and the legitimacy of administrative government are inextricably intertwined. Among other things, judicial review serves a symbolic, or im Professor Bickel's words, a "mystic" function. ${ }^{29}$ The availability of judicial review suggests that the will of the majority is always subject to the himitations of the Constitution and that government therefore operates by consent inasmuch as all citizens have agreed to government action in accordance with the Constitution. ${ }^{30}$

The ultimate success of judicial review, however, rests on the ability of the Supreme Court to articulate and impleinent principles that place administrative government within a constitutional framework. This responsibility includes both the doctrinal necessity of explaining how progressive government is consistent with hiberal values and the practical necessity of articulating a version of judicial review that is an effective check and balance on administrative government. Unless both the doctrinal and practical necessities are met when individual judicial decisions are made, judicial review will be reduced to its symbolic elenient and the legitimation of administrative government will be more inyth than reality. ${ }^{31}$

The Supreme Court has been severely criticized for its failure to articulate a theory of judicial review that accommodates progressive and

27. See J. Buchanan \& G. Tullock, The Calculus of Consent 283-95 (1962); A. DOWNS, AN ECONOMIC THEORY OF DEMOCRACY 88-95 (1957); P. QUIRK, INDUSTRY INFLUENCE IN Federal Regulatory AGenCies 143-74 (1981); Weingast, Regulation, Reregulation, and Deregulation: The Political Foundations of Agency Clientele Relationships, LAw \& CONTEMP. ProBs., Winter 1981, at 150-61.

28. See Peltzman, Toward a More General Theory of Regulation, 19 J. LAw \& Econ. 211, 211. 13 (1976); Posner, Theories of Economic Regulation, 5 BeLl J. Econ. \& MGMT. SC1. 335, 341-42 (1984) (discussing "capture" theory which proposes that over time regulatory agencies become dominated by the industries they regulate); Stigler, The Theory of Economic Regulation, 2 BELL J. ECON. \& MGMT. SCI. 3, 10-13 (1981). More recently, some have argued that public interest groups have had a similar impact on agency decisionmaking. See, e.g., Schoenbrod, Separation of Powers and the Powers that Be: The Consitutional Purposes of the Delegation Doctrine, 36 AM. U.L. REv. 355, 37172 (1987).

29. A. Bickel, The least Dangerous Branch: The Supreme Court at the Bar of Politics 32 (2d ed. 1986).

30. Id. at 30-31; cf. Monaghan, Marbury and the Administrative State, 83 CoLUM. L. REv. 1, 1 (1983) (public administration free from judicial oversight would damage the fundamental political axiom of limited government).

31. See M. Edelman, The Symbolic Uses of Politics $22-43$ (1964); $c f$. T. Arnold, The SYMBOLS OF GoVERNMENT 34 (1935) ("[P]art of the function of 'Law' is to give recognition to ideals representing the exact opposite of established conduct ...."). 
liberal values and legitimates adminstrative government. ${ }^{32}$ As a result, doubts remain concerning the legitimacy of the administrative process. ${ }^{33}$ The history of the Supreme Court's treatment of judicial review, discussed below, reveals the causes of that failure and the Court's recent response to it.

\section{The Evolution of Judicial Review AND the ACCOMMODation of Political Values}

Over time, three different models of judicial review of administrative action have evolved.

\section{TABLE 2}

\begin{tabular}{|c|c|c|}
\hline Model & Constitutional Basis & Issue \\
\hline Structuralism & Separation of powers & $\begin{array}{l}\text { Consistency with } \\
\text { constitutional structure }\end{array}$ \\
\hline Proceduralism & Due process & $\begin{array}{l}\text { Consistency with } \\
\text { procedural fairness }\end{array}$ \\
\hline Rationalism & ??? & $\begin{array}{l}\text { Consistency with statutory } \\
\text { purpose }\end{array}$ \\
\hline
\end{tabular}

32. See, e.g., Stewart, The Reformation of American Administrative Law, 88 HARv. L. REv. 1669, 1802-13 (1975). Professor Stewart was led by his exhaustive review of the transformation in administrative law to conclude that "no general solution-either in terms of procedural mechanisms or authoritative rules of decision-for the ... problem of administrative discretion has yet emerged." Id. at 1805. Further, Stewart announced that it was unclear to him whether any unifying conception of the relationship between administrative institutions, legal controls, private groups, and social and individual values, would ever emerge. Id. at 1813. See also J. MASHAw, BuREAUCRATIC JUSTICE: Managing Social Security Disability Claims 1 (1983) (Stewart's scholarship establishes that "the history of American administrative law is a history of failed ideas."). More recently, Professor Rabin observed:

The courts have not developed a consistent approach to controlling agency discretion. Such an approach would have to draw on a theory of administrative expertise that dealt coherently with technical and political dimensions of the regulatory process. Lacking an intelligible theoretical framework, the Supreme Court has oscillated between activism and restraint in reviewing agency decisions.

Rabin, supra note 2, at 1325.

33. See J. FREedMAN, supra note 25 , at 9 (concluding that the fact that the administrative process has been subjected to vigorous legal and political challenges over its entire history indicates continuing public unease with the legitimacy of the process itself).

Some commentators contend that this failure is the product of an inherent inability of judicial review to control administrative abuse. See, e.g., Frug, The Ideology of Bureaucracy in American Law, 97 HARV. L. REv. 1276, 1334-55 (1984) (courts cannot articulate consistent standards for intervention in bureaucratic process); Miller, Separation of Powers: An Ancient Doctrine Under Modern Challenge, 28 AD. L. REV. 299, 319-20 (1976) (courts cannot control power of executive branch); Pierce, The Role of Constitutional and Political Theory in Administrative Law. 64 TEX. L. REV. 469, 484-89, 504-07 (1985) (courts cannot effectively interpret agency organic acts embodying policy compromises). See generally J. MASHAw, supra note 32, at 16,227. We would suggest rather that the inability of judicial review to control administrative abuse has been the product of the failure to develop a coherent theory of review. 
The "structuralist" model of judicial review focused on the constitutional limits to the structure of government. This model, however, hindered the development of the regulatory state by its rigid enforcement of the doctrine of separation of powers. Eventually, popular support for progressive government forced the Court to abandon the structuralist model and instead rely on interpretation of agencies' statutory authority as the principal structural constraint on agency action. ${ }^{34}$

Abandonment of the structuralist model inherently led to a deemphasis of the separation of powers doctrine. The Court compensated for the lack of structural constraints by turning to the "proceduralist" model, which placed primary emphasis on procedural fairness. While accepting the substance of agency decisions out of deference to administrative expertise and respect for popular will, the Court hoped to control agency government by stressing requirements of procedural due process.

When that compromise failed, the Court developed its current "rationalist" model, which stresses substantive review by requiring that an agency provide adequate reasons to demonstrate a rational relationship between a decision and the agency's statutory purpose. ${ }^{35}$ While rationalism is intended to remedy the failures of the previous models, the Court

34. The reduction of structuralism reflects the widespread relativist and empiricist revolt against formalism that reshaped American thought in the first part of the twentieth century. See E. Purcell, supra note 16, at 15-30; White, From Sociological Jurisprudence to Realism: Jurisprudence and Social Change in Early Twentieth-Century America, 58 VA. L. REV. 999, 1003-18 (1972). See generally M. White, Social Thought in AMERICA: THE Revolt Against Formalism (1963). This theoretical revolt dismissed arguments that there should be natural law limits on government as "transcendental nonsense." Cohen, Transcendental Nonsense and the Functional Approach, 35 Colum. L. REv. 809, 835-39, 847 (1935). It also led Felix Frankfurter and others to challenge the suitability within a democratic society of structuralism as a form of control over progressive government. Dennis v. United States, 341 U.S. 494, 524-25 (1951) (Frankfurter, J., concurring) (rejecting a mechanical or absolutist interpretation of the first amendment); Kovacs v. Cooper, 336 U.S. 77, 95-96 (1949) (Frankfurter, J., concurring) (same). Implicit in this work was the realization that the structuralist model stood in the way of the moderu, regulatory state. A similar challenge has been made to the use of certain forms of statutory interpretation as a means of judicial control over legislative policy. See R. POSNER, The Federal COURTS: Crisis AND Reform $262-$ 72 (1985); Easterbrook, Foreword: The Court and the Economic System, 98 HARV. L. REV. 4, 14-18 (1984); Posner, Economics, Politics, and the Reading of Statutes and the Constitution, 49 U. CHI. L. REv. 263 (1982). Although the Supreme Court has not always respected that criticism, it has limited its use of statutory interpretation as a means of controlling agency actions; and the criticism has been forcefully attacked. See Macey, Promoting Public-Regarding Legislation Through Statutory Interpretation: An Intcrest Group Model, 86 CoLUM. L. REv. 223, 226-28 (1986); Sunstein, Naked Preferences and the Constitution, 84 CoLUM. L. REv. 1689, 1691-93 (1984). The relevance of this debate for judicial review of administrative action is considered infra notes 198-202 and accompanying text.

35. The decline of the structuralist and proceduralist models, and the rise of the rationalist model, is reflected in our survey of decisions by federal courts of appeals which is appended to this article. Litigants challenging administrative action raised arguments based on the structuralist model in only 82 of the 177 cases in our survey, and raised proceduralist arguments in only 55 cases. In contrast, arguments based on the rationalist model of review were raised in 152 cases. Moreover, 
has not yet demonstrated how it preserves the liberal values reflected in the Constitution.

\section{A. The Structuralist Model.}

The Supreme Court initially blocked progressive programs through constitutional doctrines restricting the power or authority of Congress or the states to regulate. ${ }^{36}$ Once the Court abandoned these efforts, ${ }^{37}$ the focus shifted to whether regulation through the creation of administrative agencies was consistent with separation of powers. ${ }^{38}$ Despite some early indications to the contrary, the Court ultimately accepted delegation of substantial judicial and legislative authority to administrative agencies. ${ }^{39}$ As a consequence, structuralism now limits agencies primarily through statutory construction of the scope of agency authority.

1. The Evolution of Structuralism. In two early cases the Supreme Court established that agencies could adjudicate without violat-

challenges to administrative action were successful in only 21 cases based on structuralism and in only 8 cases based on proceduralism, while they were successful in 46 cases based on rationalism.

36. These included economic substantive due process, see, e.g., Lochner v. New York, 198 U.S. 45 (1905) (regulation of working hours of bakers invalid because no direct relationship with promoting public health); McClosky, Economic Due Process and the Supreme Court: An Exhumation and Reburial, 1962 SuP. CT. REv. 34, a restrictive definition of the commerce clause, see, e.g., Carter v. Carter Coal Co., 298 U.S. 238 (1936) (Congress could not regulate wages and hours of coal miners because coal is produced before it becomes an article of commerce); A.L.A. Schechter Poultry Corp. v. United States, 295 U.S. 495 (1935) (Congress could not regulate the manner in which chickens were processed because processing occurred after the "flow of commerce had ceased."); United States v. E.C. Knight Co., 156 U.S. 1 (1895) (Congress could not regulate the merger of sugar companies because they were engaged in manufacturing rather than commerce.) and a restrictive definition of the general welfare clause, see, e.g., United States v. Butler, 297 U.S. 1 (1936) (Agriculture Adjustment Act unconstitutional in part because Congress could not tax one group of persons to provide direct benefits for another).

37. The Supreme Court has replaced its strict scrutiny of government regulation under substantive due process with a more lenient "minimum rationality" requirement. Compare Lochner v. New York, 198 U.S. 45, 57-58, 64 (1905) (requirement of real and substantial relationship) with West Coast Hotel Co. v. Parrish, 300 U.S. 379, 391 (1937) (requirement of "reasonable" relationship). See United States v. Carolene Products Co., 304 U.S. 144, 152 (1938) (existence of facts supporting a rational relationship may be presumed). Some commentators have argued that a reinvigoration of the substantive due process doctrine is desirable. See R. EPSTEIN, supra note 6 (arguing that many common forms of regulation involve taking of private property which requires compensation). The Court has completely abandoned its prior attempts to establish some economic arcas as outside the scope of the commerce power. See Wickard v. Filburn, 317 U.S. 111, 128-29 (1942) (Congress may regulate wheat production intended for home consumption because of cumulative impact on interstate commerce); NLRB v. Jones \& Laughlin Steel Corp., 301 U.S. 1, 37-38 (1937) (Congress may regulate intrastate activities such as vages and hours of workers when they have a "close and substantial relationship" to some social problem affecting interstate commerce.). The Court also has changed its restrictive reading of the general welfare clause. L. TRIBE, AmERicaN ConstituTIONAL LAW $\S 5-10$ (1978).

38. See infra notes 45-48.

39. See infra notes 49-51. 
ing Article III provisions vesting "judicial power" in federal courts staffed by an independent judiciary. ${ }^{40}$ In the first case, Murray's Lessee $v$. Hoboken Land and Improvement Co., ${ }^{41}$ the Court held that an administrative official could summarily determine whether a taxpayer owed money to the government because that controversy involved "public rights." In the second case, Crowell v. Benson, ${ }^{42}$ the Court upheld the right of an agency to adjudicate even "private rights," such as the liability of an employer for an injury to an employee. Although the Court's inore recent decision in Northern Pipeline Construction Co. v. Marathon Pipe Line Co. ${ }^{43}$ reveals that there are limits to Congress's ability to grant authority to non-Article III courts to determine private rights, Marathon suggests that those limits are very broad. ${ }^{44}$

The Court has also established that agencies can legislate without violating the Article I requirement that "[a]11 legislative powers shall be vested in a Congress of the United States." 45 The Court has consistently declined to follow Schechter Poultry Corp. v. United States, ${ }^{46}$ a 1935 case which declared legislation unconstitutional because Congress had not restricted a delegation of legislative power to private parties by a suffi-

40. U.S. CONST. art. III. The independence of federal judges was protected under Article III through provisions granting them life tenure and precluding diminution of salaries.

41. 59 U.S. (18 How.) 272, 284 (1855).

42. 285 U.S. 22,49 (1932). The Court held that as long as there was a right of review by a federal judge, even under a scope of review that required deference to the substance of an agency decision, the requirements of Article III were satisfied. It declared, however, that judicial review of questions of law, and of any "fundamental" or "jurisdictional" fact whose existence was essential to the agency's statutory power to take the challenged action, required de novo judicial review. Id. at 54. See also Ohio Valley Water Co. v. Borough of Ben Avon, 253 U.S. 287, 289 (1920) (due process clause requires that any constitutional fact must be subject to de novo judicial review). The Court, however, has followed neither requirement. It commonly gives deference to some questions of law such as an agency interpretation of its enabling act. See infra notes 59-60 and accompanying text. Furthermore, the "constitutional fact doctrine" produced by these cases is now moribund. See Estep v. United States, 327 U.S. 114, 142 (1946) (Frankfurter, J., concurring); Dickinson, Crowell v. Benson: Judicial Review of Administrative Determinations of Questions of "Constitutional Fact," 80 U. PA. L. REV. 1055 (1932). In only one of the cases in our survey was this doctrine argued to the court, and in that case it was unsuccessful. Quivira Mining Co. v. EPA, 765 F.2d 126, 128 (10th Cir. 1985).

43. 458 U.S. 50 (1982) (striking down broad grant of judicial power to bankruptcy courts under the Bankruptcy Act of 1978).

44. Id. at 80-81. The Court's more recent majority decision in Commodities Futures Trading Comm'n v. Schor, 106 S. Ct. 3245 (1986), confirms that Congress can exercise considerable latitude in authorizing non-Article III courts to determine private rights under their pendent jurisdiction.

45. U.S. CONST. art. I, $\S 1$. The legislative power is checked through popular election of legislators, $i d$., and by bicameralism and presentment to the President for exercise of his veto power. See INS v. Chadha, 462 U.S. 919, 954 (1983).

46. 295 U.S. 495, 536 (1935). See J.W. Hampton, Jr., \& Co. v. United States, 276 U.S. 394, 409 (1928) (delegation of legislative authority must include "intelligible principles" to guide agency actions). 
ciently intelligible principle. ${ }^{47}$ The Court's refusal to apply Schechter to restrict delegations to administrative agencies has led most observers to declare that the nondelegation doctrine is "dead" as a method of controlling progressive government. ${ }^{48}$

Decisions in the area of separation of powers suggest that the Court generally will allow the combination of functions so long as one branch does not jeopardize the "core functions" of another. ${ }^{49}$ Although Congress occasionally exceeds that minimal limitation, ${ }^{50}$ this interpretation accommodates the existence and operation of progressive government. ${ }^{51}$

47. In only one case, Panama Refining Co. v. Ryan, 293 U.S. 388 (1935), decided shortly before Schechter, has the Court struck down a delegation of legislative authority to the executive branch under this doctrine. The Court has distinguished Schechter on the grounds that prior administrative practice or experience provides an intelligible principle, e.g., Zemel v. Rusk, 381 U.S. 1, 18 (1965) (delegation to Secretary of State authorized "only those passport refusals and restrictions "which could fairly be argued were adopted by Congress in light of prior administrative practice" "), that other sections of the legislation provided an intelligible principle, e.g., Yakus v. United States, 321 U.S. 414, 423 (1944) (boundaries of delegation to World War II Office of Price Administration contained in statement of purposes of Act), or that the statute could be reinterpreted to meet the "intelligible principle" standard, e.g., Industrial Union Dep't v. American Petroleum Inst., 448 U.S. 607,641 (1980) (OSHA interpreted to require a finding of "significant risk" to regulate industrial chemicals).

48. See, e.g., FPC v. New England Power Co., 415 U.S. 345, 352-53 (1974) (Marshall, J., concurring) ("The notion that the Constitution narrowly confines the power of Congress to delegate authority to administrative agencies ... has been virtually abandoned by the Court for all practical purposes."). Some members of the Court, however, have urged the revitalization of the nondelegation doctrine. See American Textile Mfrs. Inst., Inc. v. Donovan, 452 U.S. 490, $546-47$ (1981) (Rehnquist, J., joined by Burger, C.J., dissenting); Industrial Union Dep't v. American Petroleum Inst., 448 U.S. 607, 675 (1980) (Rehnquist, J., concurring). However, in none of the cases in our appended survey did the party challenging agency action even present a nondelegation argument. The lack of support for reinvigorating the nondelegation doctrine is not surprising, because it would cnd progressive government. See R. PIERCE, S. SHapIRo \& P. VerkuIL, supra note $23, \S \S 3.4 .3$, 3.4.4.

49. See Strauss, The Place of Agencies in Government: Separation of Powers and the Fourth Branch, 84 COLUM. L. ReV. 573, 620, 625 (1984).

50. See, e.g., Bowsher v. Synar, $106 \mathrm{~S}$. Ct. 3181 (1986) (specification to the President of spending cuts by the Comptroller General to meet budgetary limits is unconstitutional because the Comptroller General, although designated as an executive branch official, is not subject to removal by the President); INS v. Chadha, 462 U.S. 919 (1983) (legislative veto is unconstitutional because it violates bicameralism and presentment requirements for legislation); Northern Pipeline Constr. Co. v. Marathon Pipe Line Co., 458 U.S. 50 (1982) (Bankruptcy Act of 1978 unconstitutional because it granted non-Article III judges power to adjudicate broad range of private rights). But see, Commodities Futures Trading Comm'n v. Schor, $106 \mathrm{~S}$. Ct. 3245 (1986) (agency may rule on common law counterclaims pendent to issues properly before it).

51. See Bowsher v. Synar, 106 S. Ct. 3181, 3188 n.4 (1986). In Synar, the Court held that Congress could not delegate executive functions to the Comptroller General because he was not subject to removal by the President. 1 d. at 3188. The Court was careful to note, however, that its holding did not jeopardize the existence of independent agencies. Id. at 3188 n.4. Synar is consistent with previous decisions concerning the constitutionality of agency government. See Wiener $\mathbf{v}$. United States, 357 U.S. 349 (1958) (Congress may limit the President's ability to remove executive officials who engage in adjudicatory functions.); Humphrey's Executor v. United States, 295 U.S. 602 (1935) (same). In these cases, the Court approved the idea that Congress can limit the Presi- 
The Court's willingness to accept the combination of functions in modern agency government has shifted the focus of separation of powers scrutiny. Implicit in the notion of separation of powers is a corollary principle that an agency is constitutionally empowered to act only under the authority delegated to it by the legislature. ${ }^{52}$ Thus, judicial review under structuralism has been reduced to statutory interpretation to ensure that agency action is within the scope of its authority. ${ }^{53}$ The Supreme Court, however, has been unable to make up its mind about the usefulness of this form of review as a tool to limit agency discretion. As will be shown, the use of statutory construction presents a conflict between liberal and progressive values that has left the Court oscillating between activism and restraint in its use of this form of structuralism.

Industrial Union Department v. American Petroleum Institute ${ }^{54}$ (Benzene) is a good example of activism by the Court. A plurality of the Court rejected the Occupational Safety and Health Administration's (OSHA) contention that it was required by its enabling act to set very restrictive exposure limits because there was considerable doubt whether safe exposure levels for a chemical (benzene) existed. ${ }^{55}$ Instead, the plurality limited OSHA's authority by interpreting the statute to require the agency to prove that chemicals were a "significant risk" at every exposure level that was prohibited.56 Although that interpretation was based on an innovative reading of the statute, it later was confirmed by a major-

dent's power to remove agency administrators; however, in Synar the Court reaffirmed its holding in Myers v. United States, 272 U.S. 52 (1926), that Congress violates the core function of the Executive when it seeks to obtain sole control over the removal of such officers.

52. See R. Pierce, S. Shapiro \& P. Verkuil, supra note 23, § 5.1.1. The President may have constitutional authority to exercise certain powers without Congressional authority, such as the conduct of foreign affairs. Bruff, Judicial Review and the President's Statutory Powers, 68 VA. L. REV. 1, 12 (1982). These inherent powers, however, do not authorize the President to initiatc regulation. See Youngstown Sheet \& Tube Co. v. Sawyer, 343 U.S. 579 (1952).

53. See, e.g., Board of Governors v. Dimension Fin. Corp., 474 U.S. 361 (1986) (Federal Reserve Board lacks statutory authority to regulate institutions that offer services similar to banks); Macey, supra note 34, at 226-27.

54. 448 U.S. 607 (1980).

55. Id. at 615. The enabling act required the agency to set those exposure limits that "most adequately assure [ ], to the extent feasible ... that no employee will suffer material impairment" of his or her heaith. Occupational Safety and Health Act of 1970, Pub. L. No. 71-596, §6(b)(5), 84 Stat. 1590, 1594 (codified at 29 U.S.C. $\$ 655(b)(5)(1982)$ ).

56. 448 U.S. at 653. As a result, OSHA's ability to promulgate regulations has been significantly curtailed in those instances where quantifiable evidence for risk is not presently available. See Schroeder \& Shapiro, Responses to Occupational Disease: The Role of Markets, Regulation, and Information, 72 GEo. L.J. 1231, 1261 (1984). Even if the Court does not require quantifiable evidence of harm, the effect of the Court's position will be to slow the agency's regulation process by preventing the agency from using a generic cancer policy as a guideline for its regulations. Id. at 1262. 
ity of the Court. ${ }^{57}$

The Court's aggressive posture in Benzene can be contrasted with the deference exercised by the Court in Chemical Manufacturers Association v. Natural Resources Defense Council, Inc. ${ }^{58}$ The Court upheld the Environmental Protection Agency's (EPA) interpretation of the Clean Water Act concerning its authority to grant variances from pollution requirements, stating that "the agency charged with admimistering the statute is entitled to considerable deference; . . . to sustain it, we need [only] find that ... [the] EPA's understanding of this very 'complex statute' is a sufficiently rational one ...."s9 The Court announced that it could substitute its judgment for that of the agency only if "Congress has clearly expressed an intent contrary to that of the Agency."60

These two cases illustrate the dilemma of statutory interpretation under the structuralist model. On the one hand, the Supreme Court can accommodate progressive values by deferring to agency statutory interpretation. Progressivism values broad, vague delegations, which allow the solution of difficult problems through the application of agency expertise. ${ }^{61}$ The Supreme Court accepts progressivism, as it did in Chemical Manufacturers Association, when it defers to agency application of statutory language. ${ }^{62}$

On the other hand, the Supreme Court can assert liberal values by refusing to defer to agency statutory interpretation. This allows the judiciary to narrowly interpret statutes, as the Court did in Benzene, thereby limiting agency discretion. ${ }^{63}$ Such a narrowing construction, however,

57. American Textile Mfrs. Inst., Inc. v. Donovan, 452 U.S. 490,512 (1981). The Benzene plurality located the requirement of "significant risk" in 29 U.S.C. $\$ 652(8)$ (1976), which defined an occupational safety and health standard as a "standard which requires ... the adoption ... of one or more practices ... reasonably necessary or appropriate to provide safe or healthful employment." The plurality rejected OSHA's assertion that this provision required only that regulations be rationally related to the purpose of achieving a healthier work environment. 448 U.S. at $640-46$.

58. 470 U.S. 116 (1985); see Chevron U.S.A. Inc. v. Natural Resources Defense Council, Inc., 467 U.S. 837 (1984).

59. 470 U.S. at 125. The Court considered whether the EPA was entitled under the Clean Water Act to grant a variance to allow some polluters to avoid stricter discharge limitations. Congress had specified that the EPA could not "modify" those discharge limitations for certain toxic pollutants listed in the Act. 33 U.S.C. $\$ \S 1311(l), 1317(a)(1)$ (1982). The Court accepted the EPA's interpretation that the prohibition in the Act against modifications did not apply to its variance system. 470 U.S. at 134 .

60. 470 U.S. at 125 (emphasis added). The Court in applying that standard concluded that "[v]iewed in its entirety, neither the language nor the legislative history of the Act demonstrates a clear Congressional intent to forbid EPA's sensible variance mechanism." Id. at 134.

61. See supra notes 16-22 and accompanying text.

62. It also accommodates this choice when it refuses to assert a vigorous application of the separation of powers doctrine. See supra notes 49-51 and accompanying text.

63. The plurality said that its narrow construction of the statute was required to avoid declaring the statute unconstitutional under the nondelegation doctrine. 448 U.S. at 646. Some commen- 
may prevent the successful implementation of progressivism because it denies the agency discretion to determine the proper scope of regulation. ${ }^{64}$

2. The Failure of Structuralism. The structuralist model has effectively been reduced to its statutory interpretation component. The Supreme Court, by adopting tests requirmg only minimal review of agency action, seldom applies separation of powers principles to reduce agency discretion. Even in the application of statutory interpretation to limit agency power, the Court has vacillated between accepting and restricting agency discretion and often displays considerable deference toward agencies.

The reduction of structuralism has weakened the legitimacy of administrative government. The Court has accepted agency government inconsistent with the structural scheme of executive, legislative and judicial powers established in the Constitution without ever expressly addressing the inconsistency. ${ }^{65}$ This failure to address the distinctive constitutional position of the administrative agencies-their status as a "fourth branch of government" 66 _ robbed structuralism of its power to legitimate administrative government. As a result, the structuralist model retained only the symbolic, "mythical" quality.

In addition to its theoretical deficiencies, structuralism failed because it could not accommodate both progressive and liberal values at a practical level. Active use of structuralism thwarted progressive government by declaring progressive programs unconstitutional. Once the constitutionality of administrative agencies was accepted, the remaining mechanism for preventing administrative error and abuse under struc-

tators, however, believe that the plurality's rationale was really a "disguised substitution of its policies" for those adopted by OSHA. See R. PIERCE, S. SHAPIro \& P. VerkuIL, supra note 23, $\S 7.8$.

64. See infra notes $68-71$ and accompanying text.

65. Since the 1930's, for example, the Court, for purposes of the nondelegation doctrine, has engaged in the myth that agencies are part of the executive branch whose function is to fill in the details of statutes. See, e.g., Yakus v. United States, 321 U.S. 414, 426 (1944) (legislative delegation to World War II Office of Price Administration approved). In fact, agencies exercise many legislative and judicial functions. See supra notes 40-51 and accompanying text. Moreover, many agencies are not squarely within the executive branch because Congress placed limits on the President's power to remove administrative officials. The Court has upheld this independence where the agencies in question do not exercise executive power, but rather "quasi-legislative" or "quasi-judicial" powers. See Wiener v. United States, 357 U.S. 349, 353-56 (1958); Humphrey's Executor v. United States, 295 U.S. 602, 629 (1935).

66. See Report of the Committee with Studies of Administrative MaNagement iN THE FEDERAL GOVERNMENT 39-43 (1937) (complaint that government bureaucrats were outside of traditional branches of government and beyond the system of controls established for those branches). 
turalism was statutory construction. Although at times the Supreme Court has appeared to endorse this approach, albeit inconsistently, ${ }^{67}$ statutory interpretation cannot provide a practical means of controlling agency action.

First, a narrowing construction of statutes is not always available, especially where a statute is broadly worded for the precise purpose of giving the implementing agency considerable discretion. As a result, courts are often forced to defer to agency construction of authorizing statutes. ${ }^{68}$ Even where a narrowing construction is available, ${ }^{69}$ agencies usually retain substantial discretion. If a statute were in fact narrowed to the point that the agency is merely filling in the gaps, the progressive program would be frustrated.

Another problem with statutory interpretation is that it affects not only the individual decision being reviewed, but also the scope of the agency's authority to regulate in the future. ${ }^{70}$ Thus, if courts are active in construing statutes narrowly, they may undermine the regulatory framework envisioned by Congress and developed by the agency. ${ }^{71}$ In such cases, narrow statutory construction destroys the very advantages of efficiency, expertise and discretion which justify administrative government.

\section{B. The Proceduralist Model.}

With the demise of structuralism, the Court turned to proceduralist review in hopes of finding a method to legitimate agency government in terms of liberal values. ${ }^{72}$ This evolution was hardly surprising since liberal values are protected in the Constitution both by structural protec-

67. See supra notes 52-64 and accompanying text. Our survey reveals that statutory interpretation has fallen into relative disuse as a means of controlling agency action. In 95 of the 177 cases surveyed (about 54\%) the party challenging agency action did not argue that the agency had exceeded its statutory authority. However, the argument was successful in 21 of the 79 cases (about $25 \%$ ) where it was made.

68. See supra notes 61-62 and accompanying text.

69. Sec, e.g., Industrial Union Dep't v. American Petroleum Inst., 448 U.S. 607, 639-41 (1980); Hampton v. Mow Sun Wong, 426 U.S. 88, 105-14 (1976); Kent v. Dulles, 357 U.S. 116, 130 (1958).

70. See, e.g., Schroeder \& Shapiro, supra note 56, at 1261-62 (OSHA's interpretation of Benzene slowing efforts to regulate carcinogens in workplace).

71. Of course, an agency's interpretation of a statute may be contrary to the intent of Congress, and in such cases a narrowing construction would properly constrain the agency. Statutes, however, are usually sufficiently vague that any exact determination of legislative will is difficult. In such cases, the use of the rationalist model may be preferable to a narrow construction of an agency's statutory authority, because it offers a means of constraining the agency by forcing the articulation of reasons without making a difficult, and potentially erroneous, interpretation of the agency's enabling statute. See infra notes 243-24t and accompanying text.

72. See Cass, Models of Administrative Action, 72 VA. L. REv. 363, 364 (1986) (toward the end of New Deal era administrative law began to focus on process). 
tions (largely abandoned with the reduction of the structuralist model), and by individual rights, which the proceduralist model sought to enforce in the form of due process. Proceduralism ultimately failed when it was recognized that the imposition of procedures was counterproductive and often unrelated to the substance of agency decisions.

1. The Evolution of Proceduralism. Iromically, one impetus for the proceduralist orientation was Schechter Poultry Corp. v. United States, ${ }^{73}$ where the Court's conclusion that the National Industrial Recovery Act (NIRA) violated the nondelegation doctrine was based in part on the absence of administrative procedures in the Act. ${ }^{74}$ The Court's reasoning intimated that otherwise unconstitutional delegations might pass muster if parties subject to an agency's regulatory efforts were afforded sufficient procedural protection. ${ }^{75}$ This intimation was significant because it signaled a willingness to avoid the use of structuralism, in the form of the nondelegation doctrine, provided there were procedural safeguards to check admimistrative discretion. ${ }^{76}$

Congress adopted the solution suggested by the Court in Schechter when it passed the Administrative Procedure Act (APA) in 1946.77 Congress created the APA as a "working compromise, in which broad delegations of discretion were tolerated as long as they were checked by extensive procedural safeguards."78 As a result, Congress established

73. 295 U.S. 495 (1935).

74. Id. at 533. The Court explained that its prior approval of the Federal Trade Commission Act was partially based on the fact that the Commission decisions were made "upon evidence" through the use of a "quasi-judicial" body. By comparison, the Court found that the NIRA dispensed "with [that type of] administrative procedure and with any administrative procedure of an analogous character." Id.

75. Id. at 54I. The Court concluded that the NIRA was without precedent because "[i]t supplies no standards for any trade, industry or activity" and because "[i]t does not undertake to prescribe rules of conduct to be applied to particular states of fact determined by appropriate administrative procedure." Id.

76. 295 U.S. at 533; see Southern Ry. v. Virginia, 290 U.S. 190, 197 (1933) ("But if we assume that a state legislature may determine what public welfare demands and by direct command require a railway to act accordingly, it by no means follows that an administrative officer may be empowered, without notice or hearing, to act with finality ...."); Londoner v. Denver, 210 U.S. 373, 385 (1908) ("But where the legislature of the state, instead of fixing the tax itself, commits [it] to some subordinate body . . . due process of law requires that, at some stage of the proceedings, ... the taxpayer shall have an opportunity to be heard, of which he must have notice ...."). This due process requirement of procedural safeguards has been limited to decisions of a "judicial" nature, see infra notes 92-93 and accompanying text, whereas the procedures implicitly required by Schechter would apply to legislative decisions as well.

77. Administrative Procedure Act of 1946, Pub. L. No. 79-404, 60 Stat. 237 (codified at 5 U.S.C. $\S \S 551-559(1982)$ ).

78. Stewart \& Sunstein, Public Programs and Private Rights, 95 HaRv. L. REv. 1193, 1248 (1982); see S. Kelman, Regulating America, Regulating Sweden: A Comparative STudy of Occupational Safety and Health Policy 139 (1982) ("The history of administra- 
procedural requirements in the APA that went beyond the obligations of due process. ${ }^{79}$

The movement to assert liberal values in the form of additional procedural requirements culminated in two series of opinions issued by the United States Court of Appeals for the District of Columbia Circuit in the 1970 s. ${ }^{80}$ In the first, the circuit interpreted section 553 of the APA to expand the procedures required for informal rulemaking. The court in effect imposed a paper hearing requirement through its interpretation of the concepts in section 553 of "adequate notice," ment of basis and purpose." 82 In the second, several judges in the circuit required agencies engaged in rulemaking to use adjudicatory procedures not required by the APA for rulemaking. ${ }^{83}$

In Vermont Yankee Nuclear Power Corp. v. Natural Resources Defense Council, Inc., ${ }^{84}$ the Supreme Court brought the second type of expansion to an abrupt halt. The Court reversed a decision by the District

tive procedure in the United States is one of the imposition of adversary proceedings on government agencies, conceived in a way to deal with objections to the very legitimacy of administrative decision making."). See generally Verkuil, The Emerging Concept of Administrative Procedure, 78 Colum. L. REV. 258, 264-79 (1978) (history of development of APA).

79. For example, agencies must follow adjudicatory procedures whenever Cougress requires a liearing on the record. 5 U.S.C. $\$ 554(2)$ (1982). By comparison, the Due Process Clause requires some type of hearing only when agency action affects a "property" or "liberty" interest. U.S. CONST. amend. IV. Similarly, agencies that promulgate "rules" must follow the APA's rulemaking procedures, unless a limited set of exceptions apply. 5 U.S.C. § 553(a) (1982). By comparison, the Supreme Court continues to follow its lolding in Bi-Metallic Inv. Co. v. State Bd. of Equalization, 239 U.S. 441,446 (1915), that an agency that engages in rulemaking has no constitutional obligation to hold a hearing except when a rule affects a relatively small number of persons, who are exceptionally concerned, and their concern is based in each case on individualized grounds. See, e.g., United States v. Florida E. Coast Ry., 410 U.S. 224, 244-45 (1973).

80. See generally Scalia, Vermont Yankee: The APA, the D.C. Circuit, and the Supreme Court, 1978 SUP. CT. REv. 345.

81. See, e.g., United States v. Nova Scotia Food Prods. Corp., 568 F.2d 240, 252 (2d Cir. 1977) (agency must give new notice if it significantly changes the data or methodology on which it will base a rule); Portland Cement Ass'n v. Ruckelshaus, 486 F.2d 375, 394-95 (D.C. Cir. 1973) (prior to rulemaking, agency must reveal data and methodologies on which it intends to rely), cert. denied, 417 U.S. 921 (1974).

82. See, e.g., Portland Cement Ass'h, 486 F.2d at 393 (agency's failure to respond to public comments in its statement of basis and purpose ground for reversal); Automotive Parts \& Accessories Ass'n v. Boyd, 407 F.2d 330, 338 (D.C. Cir. 1968) (statement of basis and purpose must allow court "to see what major issues of policy were ventilated by the informal proceedings and why the agency reacted to them as it did").

83. See, e.g., Natural Resources Defense Council, Inc. v. NRC, 547 F.2d 633, 653 (D.C. Cir. 1976) (suggesting uumerous procedures the agency can follow but not stating any preference), rev'd, 435 U.S. 519 (1978); Ethyl Corp. v. EPA, 54I F.2d 1, 67 (D.C. Cir.) (en banc) (Bazelon, C.J., concurring) ("It is not enough for an agency to prepare a record compiling all the evidence it relied upon for its action; it must also organize and digest it."), cert. denied, 426 U.S. 941 (1976); Mobil Oil Corp. v. FPC, 483 F.2d 1238, 1253 (D.C. Cir. 1973) (purposes and provisions of substantive statute being adminstered may require more procedural safeguards than those provided in the APA).

84. 435 U.S. 519 (1978). 
of Columbia Circuit compelling the Nuclear Regulatory Commission to employ procedures inore demanding than those required by the APA for informal rulemaking. The Court held that procedural requireinents in addition to those required by the APA could not be imposed by the federal courts "[a]bsent constitutional constraints or extremely compelling circumstances ...."85 This strong language is also likely to discourage expansive use of section 553 to require paper hearings. ${ }^{86}$

After Vermont Yankee, unless Congress authorizes additional procedures, ${ }^{87}$ the courts apparently are powerless to order them except as a matter of due process. Congress recently considered an expansion of the APA, including additional procedures for rulemaking, but such legislative efforts appear to have died out. ${ }^{88}$

2. The Failure of Proceduralism. The proceduralist orientation of administrative law reflected the "legal process" conception of judicial review advanced by scholars in the 1940 s and 1950 s, which focused on the relative institutional competence of courts, legislatures and agencies to make and implement social policy decisions. ${ }^{89}$ Adıninistrative law scholars emphasized the comparative advantage of courts coordinating the procedural requirements by which agencies operated and the comparative disadvantage of the courts second-guessing the "expert" sub-

85. Id. at 543. The Court gave no indication what would constitute "compelling circumstances." For further discussion of the Vermont Yankee decision, see infra notes 157-165 and accompanying text.

86. See, e.g., Association of Data Processing Serv. Orgs. v. Board of Governors, 745 F.2d 677, 684 (D.C. Cir. 1984) (Scalia, J.) (notice requirement in informal rulemaking requires only disclosure of "most critical" factual material to be relied on by agency). Our survey reflects the decline of proceduralism after Vermont Yankee. In 122 of 177 cases (approximately 69\%) procedural objections were not raised by the party challenging agency action, and procedural challenges were successful in only 8 of the 55 cases (approximately 15\%) in which they were raised.

87. In some arcas, Congress created "hybrid" procedures. See, e.g., Clean Air Act Amendments of 1977, Pub. L. No. 95-95, 91 Stat. 685; Federal Trade Commission Improvement (Magnuson-Moss) Act of 1974, Pub. L. No. 93-637, § 202, 88 Stat. 2183, 2193-98 (1975); Occupational Health and Safety Act of 1970, Pub. L. No. 91-596, $\S \S 10-12,84$ Stat. 1590, 1601-05.

88. The highwater mark of these efforts was the Regulatory Reform Act, S. 1080, 97th Cong., 2d Sess. 128 CoNG. REC. 5276-5306 (daily ed. Mar. 24, 1982) (passed 94-0 by the Senate).

89. See, e.g., H. Hart \& A. Sacks, The Legal Process: Basic Problems in the Making AND Application of LAw (1958). See generally Ackerman, Book Review, DaEdalus 119, 123 (Winter 1974) (discussing the legal realists' challenge to proceduralism). Hart and Sacks and their colleagues were concerned, in part, that the Supreme Court avoid overstepping the limits of its function by taking itself into areas of decisionmaking in which it was not equipped to deal and which involved clashes with other branches of government. They warned that unless the Court heeded this admonition, it would not be effective as a mediator of the country's important social disputes. See Kronman, Alexander Bickel's Philosophy of Prudence, 94 YAL. L.J. 1567, 1609-12 (1985) (discussing the virtues of prudential, incremental change); White, The Evolution of Reasoned Elaboration: Jurisprudential Criticism and Social Change, 59 VA. L. REV. 279, 290 (1973). 
stantive policy decisions of those agencies. 90 This approach, however, suffered from two fundamental flaws.

First, proceduralism failed at the theoretical level because, like structuralism, it did not acknowledge the distinct position of administrative agencies in the constitutional framework. This problem was particularly evident in the context of rulemaking. As long as the Court adhered to its holding in Bi-Metallic Investment Co. v. State Board of Equalization $^{91}$ that due process requires no procedural checks upon legislative decisions by administrative agencies, ${ }^{92}$ the usefulness of proceduralism as a legitimating theory was substantially diluted. Bi-Metallic allowed Congress to determine what procedures are required when an agency engages in rulemaking. Since Congress would be free to repeal any procedural requirements used in agency rulemaking, the Constitution would impose no procedural constraints on agency rulemaking. As a result, proceduralism can not reconcile the use of rulemaking in progressive government with liberal values. ${ }^{93}$

90. See B. ACKerman, Reconstructing American Law 39 (1984). Both administrative law treatises and casebooks of this period dealt primarily with proceduralism. Little or no attention was given to the substance of regulation except to stress that the courts had a limited scope of review over substantive agency matters. See, e.g., L. JAFFe \& N. NATHANSON, Administrative Law: CASES AND MAterials (3d ed. 1968); L. JAFFe, Judicial CONTROL OF AdMinistrative Action 152-59 (1965). For expression of this theory in a judicial context, see Ethyl Corp. v. EPA, 541 F.2d 1, 66 (D.C. Cir.) (en banc) (Bazelon, C.J., concurring), cert. denied, 426 U.S. 941 (1976).

91. 239 U.S. 441 (1915).

92. Id. at 445; accord United Stales v. Florida E. Coast Ry., 410 U.S. 224, $245-46$ (1973); see supra note 79. But see supra note 76 (suggesting procedural regularity implicitly required by Schechter applies to legislative decisions by agencies). To the extent that these cases imply that separation of powers does not require adequate reasons review of legislative decisions by agencies, the authors would argue that they are wrongly decided. See infra notes 180-197 and accompanying text.

93. In Bi-Metallic, Justice Holmes thought procedural safeguards upon agency action were unnecessary because no such safeguards were required when the legislature acted. 239 U.S. at 445. Justice Holmes assumed that administrative agencies engaged in their legislatively-delegated rulemaking authority should be considered the functional equivalent of the legislature. While this assumption might be valid for purposes of due process, it is faulty insofar as separation of powers is concerned. Since agencies are not subject to the same constitutional and political constraints as legislatures, reliance solely on political safeguards to check agency action is inappropriate, and some other form of legitimation is necessary. Of course, federal separation of powers concerns were not at issue in Bi-Metallic; it involved federal review of state action. See, e.g., Minnesota v. Clover Leaf Creamery Co., 449 U.S. 456, 461 n.6 (1981); Whalen v. United States, 445 U.S. 684, 689 n.4 (1980); Mayor of Philadelphia v. Educational Equality League, 415 U.S. 605, 615 n.13 (1974).

However, the wholesale adoption of the Bi-Metallic principle in the federal context by United Slates v. Florida E. Coast Ry., 410 U.S. 224, 245-46 (1973), should not be read as implying that the constitution requires no separation of powers safeguards when a federal agency engages in rulemaking. $C$. supra note 79 . Thus, we argue that separation of powers requires heightened scrutiny of both legislative and judicial decisions by administrative agencies. See infra notes 180-197 and accompanying text. 
Second, judicial review under proceduralism did not provide a practical mechanism for reconciling progressive and liberal values. Proceduralism sought to preserve progressive values in the form of administrative autonomy by retaining the extremely deferential scope of review set under structuralism. ${ }^{94}$ This approach was premised on the assumption that while agencies are expert with regard to the substantive aspects of the regulatory scheme they administer, the courts are experts on procedure. The premise that procedural regularity will necessarily prevent error and abuse, however, is open to serious challenge..$^{95}$

Moreover, the proceduralist remedy for erroneous decisions-requiring additional procedures-threatened to destroy the very advantages of efficiency and expert discretion for which decisionmaking power is given to agencies. ${ }^{96}$ If courts can reverse erroneous decisions only by ordering additional procedures, review becomes little more than a series of agency decisions, followed by judicial remands for additional procedures. ${ }^{97}$ More importantly, as the Court recognized in Vermont Yankee,

94. See infra notes 143-147 and accompanying text.

95. A number of scholars have contended that requiring agencies to comply with additional procedures does not improve agency decisionmaking. See, eg., Boyer, Trade Regulation Rulemaking Procedures of the Federal Trade Commission, 1979 ADMinistrative Conference of THE United States: Recommendations AND Reports 41; Trade Regulation Rulemaking Procedures of the Federal Trade Commission (Phase II), 1980 Administrative Conference of THE UNITED STATES: RECOMMENDATIONS AND REPORTS 33, 124-27 (concluding that hybrid procedures used by the FTC under the Magnuson-Moss Warranty-Federal Trade Commission Improvement Act did not improve accuracy, faimess or acceptability of FTC decisions); Sax, The (Unhappy) Truth about NEPA, 26 OKLA. L. REv. 239, 239 (1973) (arguing against additional procedures). But see Pedersen, Formal Records and Informal Rulemaking, 85 YALE L.J. 38, 88 (1975) (favoring additional procedures); Stewart, The Development of Administrative and Quasi-Constitutional Law in Judicial Review of Environmental Decisionmaking: Lessons from the Clean Air Act, 62 IowA L. Rev. 713, 766 (1977) (same).

More importantly, even if it is true that procedural regularity has a salutory impact on administrative decisionmaking, it does not follow that procedures alone will prevent errors and abuse. As long as the requisite procedures are followed, proceduralism provides a court with no tools to police administrative decisionmaking. Thus, agencies can "jump through the hoops" to ensure that their decisions will be upheld, without regard to the content of the actual decision. To the extent that substantive review is undertaken, proceduralism, like structuralism, provides no guidance as to how it should be performed.

96. See National Petroleum Refiners Ass'n v. FTC, 482 F.2d 672, 690-91 (D.C. Cir. 1973) (informal rulemaking has numerous policy advantages as compared to adjudication), cert. denied, 415 U.S. 951 (1974); Shapiro, Scientific Issues and the Function of Hearing Procedures: Evaluating the FDA's Public Board of Inquiry, 1986 DuKe L.J. 288, 296-97 (informal rulemaking sufficient to consider most types of regulatory disputes); Robinson, The Making of Administrative Policy: Another Look at Rulemaking and Adjudication and Administrative Procedure Reform, $118 \mathrm{U}$. PA. L. REv. 485, 516-17 (1970) (discussion of policy advantages of informal rulemaking as compared to adjudication).

97. See Pierce, The Choice Between Adjudicating and Rulemaking for Formulating and Implementing Energy Policy, 31 HASTINGs L.J. 1, 13-15 (1979) (federal encrgy policymaking inordinately delayed by frequent reversals of agency decisions and remands for further proceedings). 
agencies will be forced to use more formal procedures in run-of-the-mill cases in order to protect themselves from judicial requirements of additional procedures. 98

\section{The Rationalist Model.}

The decline of the proceduralist model led to a renewed interest in substantive judicial review as a means to assert liberal values. The Supreme Court has turned to the rationalist model to define the scope of substantive review by requiring agencies to provide a rational explanation for their decisions. The practical or theoretical underpinnings of this model, however, have not been fully articulated. Although the Court has indicated its willingness to heighten scrutiny of the rationality of agency decisions, ${ }^{99}$ neither the Court nor commentators have explained how this change serves liberal values.

1. The Evolution of Rationalism. From the beginnimg of progressive government, substantive review was understood to be a necessary element of agency accountability. Unless the courts make some determination as to whether an agency's decision serves the statutory purposes for which the agency was created, agencies would be free to ignore their authorizing legislation. ${ }^{100}$ Nonetheless, the Court originally used an extremely deferential scope of review. It asked only whether the agency's decision had some hypothetical rational relationship to the agency's statutory mission. A decision was not reversible as long as it was "conceivably" supported by the facts in the record. ${ }^{101}$ Similarly, a factual determination needed only to be supported by "substantial evidence," which was evidence that a reasonable mind might accept as adequate to support a conclusion. ${ }^{102}$ Congress codified this standard in the APA, by allowing courts to overturn agency decisions which are "arbitrary and capricious" or without "substantial evidence."103

98. 435 U.S. $519,546-47$ (1978).

99. See infra notes $191,194,196$ and accompanying text.

100. Although early Supreme Court opinions suggested that substantive review was a constitutional necessity, e.g., Crowell v. Benson, 285 U.S. 22, 46 (1932); American School of Magnetic Healing v. Mc.Annulty, 187 U.S. 94, 111 (1902), the Court has never resolved that issue. See S. BREYER \& R. STEWART, supra note 14, at 1074-75. One implication of the theory we propose is that substantive judicial review is constitutionally required when an agency exercises substantial legislative or judicial power. See infra notes 198-213 and accompanying text.

101. See Pacific States Box \& Basket Co. v. White, 296 U.S. 176, 182 (1935).

102. See Consolidated Edison Co. v. NLRB, 305 U.S. 197, 229 (1938).

103. 5 U.S.C. $\$ 706(2)(A)$, (E) (1982). This limited scope of review has both democratic and practical aspects. Judges, who are not elected, are considered less suited to make political decisions than administrators, who are accountable to elected officials for their decisions. Further, those administrators are thought to have a comparative advantage because of their expertise and familiarity 
The Court has vacillated over the degree of deference to be accorded agency decisions under the APA. In Citizens to Preserve Overton Park, Inc. v. Volpe, ${ }^{104}$ the Court described the standard for review under the arbitrary and capricious test as "searching and careful" when it reversed a decision by the Secretary of Transportation to fund a highway routed through parkland. ${ }^{105}$ In Vermont Yankee, however, the Court appeared to reject aggressive judicial review of agency action. ${ }^{106}$ Similarly, in Baltimore Gas \& Electric Co. v. Natural Resources Defense Council, Inc., 107 the Court warned that the judiciary must be "most deferential" when reviewing predictions by an agency "within its area of special expertise."

In Motor Vehicle Manufacturers Association v. State Farm Mutual Automobile Insurance Co., 108 the Court apparently returned to the stricter version of review endorsed in Overton Park. The Court indicated that an agency must explain the "rational connection" between the facts found and the regulatory decision made, ${ }^{109}$ and adequately resolve the evidentiary and policy issues before it. ${ }^{110}$ Finally, the Court could not supply a "reasoned basis" for the agency decision if the agency failed to do so."11 In sum, State Farm siguals the emergence of the Supreme Court's rationalist model of review as the basis for accommodating liberal and progressive values. ${ }^{112}$

with regulatory problems. See Pierce \& Shapiro, Political and Judicial Review of Agency Action, 59 TEX. L. REv. 1175, 1192-93 (1981).

104. 401 U.S. 402 (1971).

105. 401 U.S. at 416 . Several federal circuit court judges, most notably the late Judge Leventhal of the District of Columbia Circuit, interpreted Overton Park to require reversal if "the agency has not really taken a 'hard look' at the salient problems, and has not genuinely engaged in reasoned decision-making." See International Harvester Co. v. Ruckelshaus, 478 F.2d 615 (D.C. Cir. 1973); Leventhal, Environmental Decisionmaking and the Role of the Courts, 122 U. PA. L. REV. 509, 514, 531-33 (1974).

106. 435 U.S. at 549; see Sunstein, Deregulation and the Hard Look Doctrine, 1983 SUP. CT. REV. 177, 209.

107. 462 U.S. 87,103 (1983).

108. 463 U.S. 29 (1983). For a possible reconciliation of Baltimore Gas and State Farm, see infra note 215 and accompanying text.

109. 463 U.S. at 43 . Although this language had been used in prior cases, see infra notes $166-$ 172 and accompanying text, the Court in State Farm indicated for the first time that this test required more scrutiny than the minimal rationality test used to review legislation. 463 U.S. at 43 n.9. The Court therefore appears to have replaced earlier scope of review formulations which resembled that minimum rationality test. Whether this rejection was solely a matter of interpretation of the APA, or a new standard of review, was left unclear in State Farm. See infra notes 192-193 and accompanying text.

110. 463 U.S. at 43. For further discussion of the Court's definition of the appropriate scope of review, see infra notes $238-240$ and accompanying text.

111. 463 U.S. at 43.

112. The Court left the doctrinal basis for heightened scrutiny in doubt. More recently, a plurality of the Court in Bowen v. American Hosp. Ass'n, 106 S. Ct. 2101, 2112 (1986), amplified State 
2. The Prospects of Rationalism. Rationalism has become the primary method of constraining administrative action. ${ }^{113}$ By requiring a rational explanation for their actions, the Court seeks to put administrative agencies in the same framework that legal process scholars once thought applicable only to courts. ${ }^{114}$ This perspective argues that political and personal motivations influencing legal decisionmaking can be checked if judges are expected to give a "reasoned elaboration" for their actions according to norms of consistent, neutral and candid decisional processes. ${ }^{115}$ Similarly, rationalism requires agencies to give a "reasoned elaboration" demonstrating that their decisions serve the statutory ends for which they were created.

The Court's adoption of rationalist review comes at a time when much administrative law scholarship has moved beyond a proceduralist orientation to encompass the study of substantive, ${ }^{116}$ political ${ }^{117}$ and organizational118 aspects of regulatory decisionmaking. This scholarship suggests that administrators often act im response to self-serving political and personal motivations. ${ }^{119}$ Recognition of these motivations reinforces the necessity of substantive judicial review. Without substantive judicial review, there is no check to prevent an agency from serving the purely private interests of special interest groups at the expense of the broader

Farm's rejection of minimum rationality review for agency action without fully articulating the doctrinal basis for this rejection. See infra notes 194-196 and accompanying text.

113. Our survey showed that substantive review has become the primary mechanism for challenging agency action. Substantive challenges were made in 152 of 177 cases (about 86\%), and were successful in 46 of those cases (about $30 \%$ ). Statutory and procedural objections were raised much less frequently, and were less successful. See supra notes 78 and 86.

114. Bruff, Legislative Formality, Administrative Rationality, 63 TEx. L. REv. 207, 238 (1984) (hard look review plays "the same legitimizing role in administrative law that the jurisprudential school of 'reasoned elaboration' once held out for courts").

115. White, The Evolution of Reasoned Elaboration: Jurisprudential Criticism and Social Change, 59 VA. L. REv. 279, 286 (1973). The term "reasoned elaboration" was coined by Professors Hart and Sacks, who felt that "[t]he gradual spread of the obligation of reasoned decision and elaboration" was "one of the phenomena of contemporary law." H. HART \& A. SACKs, supra note 89, at 170.

116. See, e.g., G. Robinson, E. Gillhorn \& H. Bruff, Administrative Law and ReguLATORY POLICY (3d ed. 1986); S. BREYER \& R. STEWART, supra note 14.

117. See Cutler \& Johnson, Regulation and the Political Process, 84 YALE L.J. 1395, 1409-18 (1975); Pierce \& Shapiro, supra note 103, at 1195-1220.

118. See generally J. Mashaw, Bureaucratic Justice: Managing Social Security DisaBillty Claims (1983); Mashaw, Mirrored Ambivalence: A Sometimes Curmudgeonly Comment on the Relationship between Organization Theory and Administrative Law, 33 J. LEGAL ED. 24 (1983); Rabin, Adininistrative Law in Transition: A Discipline in Search of an Organizing Principle, $72 \mathrm{Nw}$. U.L. REv. 120, 135-45 (1977).

119. See supra note 27 and accompanying text. 
public interests the agency is supposed to serve. ${ }^{120}$

Although the Court's adoption of the rationalist model has been widely recognized, ${ }^{121}$ neither the Court nor legal scholars have articulated a complete doctrinal explanation for it. ${ }^{122}$ The conventional assumption is that the Court requires an agency to have "adequate reasons" pursuant to its judicial review function under the APA. ${ }^{123}$ This explanation, however, fails to demonstrate how rationalism protects liberal values at the constitutional level, either in terms of the structure of government or in terms of due process safeguards. Until such an explanation is provided, rationalism cannot succeed as a legitimating theory for administrative agencies.

\section{The Evolution of the Reasons ReQuirement AND The MODELS OF JUDICIAL REVIEW}

While the need for substantive review of administrative decisions has long been recognized, defining the scope of review has been a source of considerable difficulty. Underlying this difficulty is the inherent tension between correcting administrative errors and abuses on the one hand, and preserving administrative expertise and efficiency on the other. This tension reflects the broader difficulty of accommodating liberal and progressive values.

In struggling with the problem of judicial review, the Supreme Court has evolved from a structuralist, to a proceduralist, to a rationalist perspective. Structuralism and proceduralism avoided the problem of substantive review by relying on other mechanisms to control agencies, and by according considerable deference to substantive determinations by agencies. As a consequence, neither model produced principles to guide and control substantive review. Rationalism addresses the problem of substantive review by requiring that an agency give adequate reasons for its decisions.

The Court's failure to articulate the basis of rationalism, however, leaves the role of substantive review under rationalism unclear. Such an articulation requires careful examination of the history of the reasons requirement, with attention to how the reasons requirement's form and

120. Sunstein, supra uote 12, at 74-75; cf. Macey, supra note 34, at 226 (illustrating power of judiciary to strike down administrative decisions benefitting special interest groups on constitutional grounds). See generally supra note 29 and accompanying text.

121. See, e.g., Bruff, supra note 114, at 238; Diver, Policymaking Paradigms in Administrative Law, 95 HARv. L. REv. 393, $421-28$ (1981); Sunstein, supra note 12, at 49-50.

122. Rabin, supra note 2 , at 1325-26.

123. 5 U.S.C. $\$ 706(2)$; see infra note 192 and accompanying text. 
function have evolved to reflect the three models of review employed by the Court. This relationship is illustrated in Table 3.

\section{TABLE 3}

\begin{tabular}{cll} 
Model & \multicolumn{1}{c}{ Form of Requirement } & \multicolumn{1}{c}{ Function } \\
Structuralism & $\begin{array}{l}\text { Connection with Statutory } \\
\text { Authority }\end{array}$ & Demonstrate Power to Act \\
Proceduralism & $\begin{array}{l}\text { Connection with Agency } \\
\text { Record }\end{array}$ & Protect Agency Process \\
Rationalism & $\begin{array}{l}\text { Connection with Statutory } \\
\text { Objective }\end{array}$ & $\begin{array}{l}\text { Insure Fidelity to } \\
\text { Progressive Mandate }\end{array}$
\end{tabular}

The following examination of the historical relationship between the models of judicial review and the reasons requirement will help to lay the foundation for a more complete articulation of the rationalist model and the role of the reasons requirement in guiding substantive review.

\section{A. Reasons and Structuralism.}

The genesis of the reasons requirement lies in early Supreme Court cases reviewing decisions of the first federal regulatory agency in the United States-the Interstate Commerce Commission (ICC). ${ }^{124}$ In one line of cases, the Court required the ICC, as a jurisdictional prerequisite, to demonstrate the connection between an order under review and its statutory authority. In another line of cases, the Court admonished the ICC to state its reasons and factual findings for a given decision in order to facilitate judicial review. The dechine of the structuralist model led to the fusion of these two lines of authority, foreshadowing the emergence of a proceduralist version of the reasons requirement.

The seminal decision in the first line of cases was American Express Co. v. South Dakota ex rel. Caldwell, ${ }^{125}$ in which the Court upheld an ICC order affecting intrastate rates because regulation of these rates was necessary to prevent discrimination with regard to interstate rates. American Express adopted a two-part test for reviewing ICC orders affecting intrastate rates. ${ }^{126}$ First, the order in question had to be sufficiently specific regarding which rates were to be governed by the

124. See supra note 22 .

125. 244 U.S. 617 (1917).

126. The Court said:

[W] here ... there is a conflict between the federal and the state authorities, the Commission's order cannot serve as a justification for disregarding a regulation or order issued under state authority, unless, and except so far as, it is definite as to the territory or points to which it applies. For the power of the Commission is dominant only to the extent that 
order. ${ }^{127}$ Second, the order had to be accompanied by factual findings demonstrating the link between regulation of intrastate rates and the protection of interstate commerce. ${ }^{128}$

Although this doctrine originated as a product of a restrictive reading of the commerce clause, it soon was applied in the separation of powers context. In Wichita Railroad \& Light Co. v. Public Utilities Commission, ${ }^{129}$ the Court indicated that a delegation of legislative power must be limited by procedural constraints and rules of decision with which an agency must comply. When an agency's authorizing statute required factual findings, "the validity of [an] order must rest upon the needed finding." 130 Thus, the reasons requirement placed agency action within the constitutional structure of government by demonstrating that an agency had acted pursuant to a valid statutory mandate.

Initially, the requirement of necessary findings was successful. So long as the statute authorizing agency action was narrow, a simple articulation of facts to invoke that statutory authority controlled agency discretion and protected liberal values. Once the Supretne Court accepted broad delegations of authority under vaguely worded statutes, however, this early form of the reasons requirement failed as a meaningful check on agency action. Under vague statutory mandates, agencies can assert virtually any set of facts to invoke their power.

The Court seemed to recoguize this problem in Beaumont, Sour Lake \& Western Railway v. United States. ${ }^{131}$ It criticized the ICC's failure "to report the facts and give the reasons" for its decision to fix rates on a group basis, rather than for each individual carrier, but nonetheless concluded that there was sufficient evidence in the record to uphold the

\footnotetext{
the exercise is found by it to be necessary to remove the existing discrimination against interstate traffic.

Id. at 625-26.

127. Id. at 625, 627; see also Illinois Cent. R.R. v. Public Utils. Comm'n, 245 U.S. 493, 508-10 (1918) (relying on American Express to strike down an ICC order affecting intrastate rates because it lacked the requisite specificity regarding the territory or points to which it applied). This requirement of specificity appears to be a type of "clear statement" requirement derived from a restrictive conception of the federal commerce poiver under structuralism. See supra note 37 and accompanying text (describing use of restrictive interpretation of commerce power under structuralism). For discussion of the "clear statement" doctrine, see generally Krent, Avoidance and Its Costs: Application of the Clear Statement Rule to Supreme Court Review of NLRB Cases, 15 CoNN. L. REv. 209 (1983); Note, Intent, Clear Statements, and the Common Law: Statutory Interpretation in the Supreme Court, 95 HaRv. L. Rev. 892, 899-912 (1982).

128. 244 U.S. at 625 ; see also Railroad Comm'n v. Chicago, B. \& Q. R.R., 257 U.S. 563, 579-80 (1922) (evidence sufficient to support finding that intrastate rates worked undue discrimination against travelers in interstate commerce, but not to support order affecting all rates of a general description).
}

129. 260 U.S. $48,58-59$ (1922).

130. Id. at 59.

131. 282 U.S. 74 (1930). 
order. ${ }^{132}$ To address the problem of agency discretion under broad statutes, the Beaumont Court endorsed a proceduralist orientation, linking an agency's statement of reasons to the process of judicial review.

This doctrine was initially distinct from the requirements of American Express. The Court apparently did not view an agency explanation as a prerequisite for a valid order, because it upheld the order in Beaumont despite the ICC's failure to report the facts and give the reasons for its order. Nor did the Court rely on the American Express line of cases, but rather on analogy to cases emphasizing the duty of judges to state fully the grounds on which they base their decisions in order to facilitate review. ${ }^{133}$ In subsequent cases, however, the Court merged the Beaumont rationale with the American Express line of cases-suggesting a commingling of the structuralist and proceduralist perspectives. ${ }^{134}$

\section{B. Reasons and Proceduralism.}

The reasons requirement underwent further evolution in the 1940s to reflect a solely proceduralist orientation characterized by two important features. First, the requirement was understood as a procedural safeguard rather than as a demonstration of the link between agency action and an authorizing statute. Second, once reasons were given, they were accorded extremely deferential substantive review. This purely procedural understanding of the reasons requirement began to change in the 1970s, however, as the requirement became associated with the "hard look" doctrine, a movement toward stricter procedural and substantive scrutiny of agency decisions.

132. Id. at 86-87.

133. The Court explained:

The Commission's failure specifically to report the facts and give the reasons on which it concluded that under the circumstances the use of the average or group basis is justified leaves the parties in doubt as to a matter essential to the case and imposes unnecessary work upon the courts called upon to consider the validity of the order. Complete statements by the Commission showing the grounds upon which its determinations rest are quite as necessary as are opinions of lower courts setting forth the reasons on which they base their decisions in cases analogous to this.

Id.

134. The first of these cases, Florida v. United States, 282 U.S. 194, 212 (1931), reflected a continued structuralist perspective and distinguished Beaumont as involving "merely ... the absence of elaboration or of a suitably complete statement of the grounds of the Commission's determination," rather than "the lack of the basic or essential findings." Id. at 215. However, in United States v. Chicago, M. St. P. \& P. R.R., 294 U.S. 499, 510-11 (1935), the Court relied on both Beaumont and Florida v. United States, merging the two rationales. In United States v. Carolina Freight Carriers Corp., 315 U.S. 475, 488-89 (1942), the Court confused matters further by reiterating the distinction drawn in Florida v. United States, but relying on Chicago, M. St. P. \& P. R.R. as well. 
1. The Proceduralist Understanding. In Phelps Dodge Corp. v. $N L R B,{ }^{135}$ the Court reversed a National Labor Relations Board decision ordering reinstatement of strikers who had already found subsequent employment. The Court reasoned that while the Board had ample discretion to make such an order, the record did not reveal why it chose to do so in this case. Noting that "[t]he admmistrative process will best be vindicated by clarity in its exercise," the Court concluded that without a statement of reasons, it could not exercise its judicial review function to ensure that the Board "has exercised the discretion with which Congress has empowered it."136 Thus, the Court reversed and remanded the case to the Board for an explanation of its decision. ${ }^{137}$ Phelps Dodge was an important step in the transformation of the reasons requirement to its proceduralist form. The Court incorporated the process-oriented rationale from Beaumont, but, unlike Beaumont, treated the failure of the agency to give reasons as grounds for reversal. ${ }^{138}$ Phelps Dodge, however, did not abandon the separation of powers understanding of the requirement. ${ }^{139}$

The Court's two decisions in the famous Clienery litigation completed the transformation of the reasons requirement. In SEC v. Chenery Corp. (Chenery $I), 140$ the Court struck down the Security and Excliange Commission (SEC) determination that the former controlling shareholders' participation in a reorganized public utility holding company would violate the Public Utility Holding Company Act. The Court remanded the case to the SEC, holding that "an administrative order cannot be upheld unless the grounds upon which the agency acted in exercising its powers were those upon which its action can be sustained."141 The

135. 313 U.S. 177 (1941).

136. Id. at 197 (emphasis added).

137. Id. at 200.

138. Beaumont indicated that a statement of reasons would be desirable, but approved the order under consideration anyway. This implied that a statement of reasons was not a requirement. See supra note 132 and accompanying text. The Court in Phelps Dodge did not cite Beaumont or the American Express line of cases.

139. The Court stated:

Since Congress has defined the authority of the Board and the procedure by which it must be asserted and has charged the federal courts with the duty of reviewing the Board's orders .... it will avoid needless litigation and make for effective and expeditious enforcement of the Board's order to require the Board to disclose the basis of its order.

313 U.S. at 197.

140. 318 U.S. 80 (1943).

141. Id. at 95. The SEC had based its order on judicial decisions which it believed created a common law fiduciary duty prohibiting participation by corporate officers and directors in the reorganization of a corporation they control. While this explanation for the decision was rejected by the Court, it refused to reverse the SEC's decision outright because such a prohibition might be upheld as an exercise of the SEC's discretion under the Public Utility Holding Company Act. However, the Court also refused to uphold the order on that basis, because to do so would be to substitute its 
Court's discussion reflected a proceduralist conception of the reasons requirement, emphasizing that "the courts cannot exercise their duty of review unless they are advised of the considerations underlying the action under review" and that "the process of review requires that the grounds upon which the administrative agency acted be clearly disclosed and adequately sustained."142 Despite this emphatic declaration, the Court emphasized deference to agency expertise and upheld the initial SEC order in SEC v. Chenery Corp. (Chenery II). ${ }^{143}$

Subsequent developments consolidated the proceduralist understanding of the reasons requirement and de-emphasized its separation of powers component. As a procedural safeguard, the requirement was intended to protect liberal values by ensuring meaningful public participation before the agency. First, an articulation of reasons was a requirement of due process at the agency level. ${ }^{144}$ Second, by connecting a given result reached by an agency with the record generated by the proceedings, the articulation of reasons would facilitate judicial review of

discretion for that of the agency. Thus, the Court concluded it was required to remand the case to the agency. Id. at 94-95.

142. Id. at 94; accord Atchison, T. \& S.F. Ry. v. Wichita Bd. of Trade, 412 U.S. 800, 807, 809 (1973); FTC v. Sperry \& Hutchinson Co., 405 U.S. 233, 249 (1972); NLRB v. Metropolitan Life Ins. Co., 380 U.S. 438, 442-44 (1965); Burlington Truck Lines, Inc. v. United States, 371 U.S. 156, 16769 (1962).

143. 332 U.S. 194 (1947). Together, the two Chenery decisions underscore that in its proceduralist form the reasons requirenent is relatively unconcerned with the result reached by an agency as long as that result is supportcd by reasons.

It is difficult to reconcile the extrene deference accorded the SEC's reasons in Chenery II, with the Court's apparently activist posture in Chenery $I$. One possible explanation for the Court's apparent refusal to inquire into the substance of the reasons offered by the SEC on remand was suggested by Justice Jackson in his dissent-"a shift in attitude between that of the controlling membership of the Court when the case was first [before it] and that of those who [had] the power of decision on [the] second review." Id. at 210. Putting aside this political explanation, Chenery $I$ is probably best understood as a case involving a "pure question of law," which under the jurisprudence of the time was to be reviewed de novo by the courts. Compare, e.g., NLRB v. Hearst Publications, Inc., 322 U.S. 111, 129 (1944) (application of a broad statutory term to particular facts requires deferential review) with Packard Motor Car Co. v. JNLRB, 330 U.S. 485, 493 (1947) (giving agency no deference in deciding "naked question of law").

144. See, e.g., Wolff v. McDonnell, 418 U.S. 539, 564-65 (1974); Goldberg v. Kelly, 397 U.S. 254, 271 (1970); Hameetman v. City of Chicago, 776 F.2d 636, 645 (7th Cir. 1985); Friendly, "Some Kind of Hearing," 123 U. PA. L. REv. 1267, 1292 (1975); see also Verkuil, $A$ Study of Informal Adjudication Procedures, 43 U. CHI. L. REv. 739, 790 (1976) (majority of informal agency adjudications include statement of reasons as procedural safeguard). Since procedural safeguards required by due process are currently understood to apply only in the context of adjudicatory decisions by agencies, see supra note 79, a statement of reasons arguably is not required by due process when an agency engages in rulemaking. However, the APA imposes such a requirement in informal rulemaking through section 553's requirement of a concise statement of basis and purpose. 5 U.S.C. \& 553(c) (1982). This understanding of the nature of the reasons requirement in its proceduralist form contributed to the failure of proceduralism as a legitimating theory. See supra notes $92-93$ and accompanying text. 
decisions made under broad statutory mandates. ${ }^{145}$ Thus, the primary emphasis of reasons under procedurahism was to connect an agency decision to an evidentiary record, rather than to the agency's statutory authority (as was the case under structurahism). Because the records produced became large and unwieldy, however, they frequently were capable of supporting virtually any result. ${ }^{146}$ Thus, as suggested by Justice Jackson in his Chenery $I I$ dissent, ${ }^{147}$ requiring agencies to state reasons offers no protection unless the substance of those reasons was subjected to reasonable scrutiny.

\section{The "Hard Look" Gloss. In Citizens to Preserve Overton Park,} Inc. v. Volpe, ${ }^{148}$ the Court appeared to respond to this problem by endorsing more rigorous review of agency action pursuant to the APA. It stated that "the generally applicable standards of $\S 706$ [of the APA] require the reviewing court to engage in a substantial imquiry" and that while an agency's action was entitled to a presumption of regularity, that presumption would not "shield [its] action from a thorough, probing, indepth review."149 This review, according to the Court, would require judicial inquiry into whether the agency acted within the scope of its statutory authority, whether the agency action was arbitrary and capricious, and whether the agency had followed all necessary procedures. 150

Prompted by Overton Park, lower courts began to engage in "hard look" review of both substantive and procedural agency action. ${ }^{151}$ In this early form, substantive hard look review was closely allied with proceduralism. The reasons requirement was often characterized as procedural, ${ }^{152}$ and the substantive inadequacy of an agency's reasons was addressed through procedural remedies, ${ }^{153}$ such as requiring "hybrid" procedures to create a more thorough record. ${ }^{154}$ These "hybrid" proce-

145. See supra notes 136,142 and accompanying text.

146. See S. BREYER \& R. STEWART, supra note 14 , at 415-16.

147. Justice Jackson argued that the result "makes judicial review of administrative orders a hopeless formality for the litigant, even where granted to him by Congress. It reduces the judicial process in such cases to a mere feint." 332 U.S. at 210.

148. 401 U.S. 402 (1971).

149. Id. at 415 .

150. Id. at 416 .

151. See Garland, Deregulation and Judicial Review, 98 HARv. L. REv. 505, 549 n.248 (1985); Rodgers, A Hard Look at Vermont Yankee: Environmental Law Under Close Scrutiny, 67 GEO. L.J. 699,705 (1979). We believe that these substantive elements were the initial manifestations of the rationalist model of judicial review.

152. See, e.g., Stewart, Paradoxes of Liberty, Integrity and Fraternity: The Collective Nature of Environmental Quality and Judicial Review of Administrative Action, 7 ENVTL. L. 463, 480 (1977).

153. See supra notes $80-83$ and accompanying text.

154. See, e.g., Marcel, The Role of the Courts in a Legislative and Administrative Legal SystemThe Use of Hard Look Review in Federal Environmental Litigation, 62 OR. L. REv. 403, 429-32 
dures were generally derived from the requirements of section 553 of the APA, rather than from the reasons requirement articulated in Chenery I. ${ }^{155}$ Nonetheless, the reasoning process used to require these additional procedural safeguards was analogous-the failure to explain a given result deprived affected parties of meaningful participation in the agency decision and frustrated judicial review, requiring imposition of additional procedures. ${ }^{156}$

Vermont Yankee Nuclear Power Corp. v. Natural Resources Defense Council, Inc. ${ }^{157}$ recognized the unsuitability of procedural remedies for substantive inadequacy of agency decisions. The court of appeals reversed a Nuclear Regulatory Commission (NRC) rule. This "zero-risk assumption" rule stated the NRC would not consider the risks of longterm storage of nuclear waste individually for each nuclear power plant in deciding whether to issue a license. In addition, the appellate court required further procedures for the agency to follow on remand. ${ }^{158}$ The Supreme Court emphatically held that reviewing courts were not to require agencies to engage in procedures beyond those required by statute or the Constitution. ${ }^{159}$ The Court reasoned that judicial imposition of added procedures would overformalize the administrative process, and criticized the circuit court for assuming that "additional procedures will automatically result in a more adequate record because it will give interested parties more of an opportunity to participate in and contribute to the proceedings." 160

(1983). The degree to which judicial review of agency action should emphasize substantive or procedural elements of review was the subject of considerable debate within the District of Columbia Circuit. The emphasis on substantive hard look was championed by, among others, the late Judge Leventhal, while Chief Judge Bazelon was a leading exponent of a procedural emphasis. Compare, e.g., Ethyl Corp. v. EPA, 541 F.2d 1, 66-67 (D.C. Cir.) (en banc) (Bazelon, C.J., concurring) (favoring procedural remedies), cert. denied, 426 U.S. 941 (1976) with id. at 68-69 (Leventhal, J., concurring) (advocating mcaningful substantive review).

155. See supra notes $78-80$ and accompanying text. That the proceduralist conception of the requirement continued to dominate these decisions is suggested by the derivation in these cases of the requirement from section 553's provision for a "concise statement of basis and purpose" for a rule rather than section 706(2)(A)'s "arbitrary and capricious" standard of review. Section 553 governs procedures while section 706(2)(A) concerns substantive review. It is therefore no coincidence that the reasons requirement under the rationalist model tends to be associated with the arbitrary and capricious standard of review, rather than section 553. See infra notes 170-177 and accompanying text.

156. See generally S. BREYER \& R.. STEWART, supra note 14, at 699-705.

157. 435 U.S. 519,558 (1978).

158. Natural Resources Defense Council, Inc. v. NRC, 547 F.2d 633, $653-55$ (D.C. Cir. 1976), rev'd, 435 U.S. 519 (1978). While the language of the circuit court's opinion left unclear whether the NRC was required to engage in additional procedures, the Supreme Court concluded that additional procedures had been required. See Vermont Yankee, 435 U.S. at 535.

159. Vermont Yankee, 435 U.S. at 546; see supra notes $84-85$ and accompanying text.

160. 435 U.S. at 547. The utility of requiring agencies to follow additional procedures was the source of considerable debate. See supra note 95 . The reasons requirement in its proceduralist cast 
Although it concluded that the NRC had satisfied the procedural requirements of the APA (and thus that the rule was not procedurally deficient), the Court nevertheless refused to approve the rule. The Court explained that there was a separate issue of whether the "challenged rule finds sufficient justification in the administrative proceedings that it should be upheld by the reviewing court." 161 The Court remanded the case to the circuit court to engage in the appropriate substantive review of the rule. ${ }^{162}$ Thus, while the Court was unwilling to allow judicial imposition of hybrid rulemaking procedures, it retained the requirement that an agency must sufficiently justify its decisions. As a result, the Court appears to have separated the reasons requirement from its connection with proceduralism, suggesting a further evolution of the requirement. ${ }^{163}$

did not escape this controversy. Compare Sax, supra note 95, at 239 ("I know of no solid evidence to support the belief that requiring articulation, detailed findings or reasoned opinions enhances the integrity or propriety of the administrative decisions.") with Friendly, Chenery Revisited: Reflections on Reversal and Remand of Administrative Orders, 1969 DUKE L.J. 199, 207-08 (remands for more adequate explanations have significantly improved agency decisionmaking). For practical purposes, this debate was resolved against adding procedures by the Supreme Court's Vermont Yankee decision, see R. PIERCE, S. SHAP1Ro \& P. VERKulL, supra note 23, $\S 6.4 .9 \mathrm{a}$, although the decision has not been without its critics, see, e.g., $2 \mathrm{~K}$. DAVIS, ADM1NistRative LAW TREATISE $\$ 7.19$ (2d ed. 1979) (finding that judges are unable to terminate their own common law powers over review of agency decisions); Rodgers, supra note 151, at 727 (Vermont Yankee out of step with close scrutiny doctrine that has become "synonymous with contemporary judicial review of technological decisionmaking by the agencies"); Stewart, Vermont Yankee and the Evolution of Administrative Procedure, 91 HARV. L. REV. 1805 (1978) (case ignores agency shift from adjudication to rulemaking and corresponding need for courts to develop new procedures to allow valid substantive review of agency decisions). But see Byse, Vermont Yankee and the Evolution of Administrative Procedure: A Somewhat Different View, 91 HARV. L. REv. 1823 (1978) (ability to determine own rules central to efficient agency operation); Scalia, supra note 80; see also Breyer, Vermont Yankee and the Courts' Role in the Nuclear Energy Controversy, 91 HaRv. L. REv. 1833 (1978) (approving Court's rejection of additional procedures, but arguing that Court should have affirmed agency on the merits rather than remand); Neely, Vermont Yankee Nuclear Power Corp. v. Natural Resources Defense Council, Inc.: Response and Reaction in the Federal Judiciary, 14 U. BALT. L. REV. 256, 308 (1985) (calling on Supreme Court to close loopholes in Vermont Yankee to prevent lower courts from circumventing its prohibition of added procedures in informal rulemaking).

While Vermont Yankee rejected hard look insofar as it involved the imposition of procedures as a remedy for perceived defects in agency decisionmaking, it left unclear whether this rejection extended to scrutiny of the agency's reasoning process. See infra notes 164-165 and accompanying text.

161. 435 U.S. at 549. Judge Tamm had argued for reversal on this basis in his concurring opinion to the court of appeals decision. See 547 F.2d at 658-59 (Tamm, J., concurring).

162. 435 U.S. at 549.

163. Professor Byse, relying on Williams, "Hybrid Rulemaking" Under the Administrative Procedure Act: A Legal and Empirical Analysis, 42 U. CH1. L. REv. 401, 454 (1975), suggests that the type of remand implicitly approved in Vermont Yankee was simply the traditional Chenery I type remand. Byse, supra note 160, at 1827 . This suggestion ignores the development of substantive elements of the requirement in the period between Chenery II and Vermont Yankee. We agree with Professor Byse's endorsement of Vermont Yankee, because it allows courts to remand decisions which are inadequately supported while leaving the choice of additional procedures-if any-to the 
The Court, however, did not explain the basis or scope of this requirement of sufficient justification, and left the continued availability of the substantive aspects of the hard look doctrine unclear. ${ }^{164}$ Substantive hard look was closely associated with the imposition of hybrid procedures, ${ }^{165}$ and Vermont Yankee's emphatic language might be read broadly as a general discouragement of judicial activism in reviewing agency decisions. Articulation of the basis and scope of the requirement of adequate reasons was addressed in later cases laying the foundations of the rationalist model.

\section{Reasons and Rationalism.}

With the decline of structuralism and proceduralism, increased attention was devoted to the content of substantive review; the reasons requirement was adapted to this end. While this change did not become apparent until after the demise of the proceduralist aspects of hard look review in Vermont Yankee, the foundations of the reasons requirement already had been laid in Burlington Truck Lines, Inc. v. United States. ${ }^{166}$ In Burlington Truck Lines, the ICC justified an order to issue a certificate of convenience and necessity authorizing a common carrier to transport commodities as a remedy for inadequate service due to a umion boycott of other carriers in the area. ${ }^{167}$ The Supreme Court overturned the ICC order because it failed to "articulate any rational connection between the facts found and the choice made."168 The Court relied on reasoning substantially similar to that used in Chenery II and Phelps Dodge. ${ }^{169}$ Thus,

agency. See infra notes 226-233 and accompanying text. However, Chenery II employed an extremely deferential standard of review in assessing the sufficiency of an agency's reasons. See supra note 143 and accompanying text. Professor Byse's assumption that under Vermont Yankee reversal and remand for inadequate reasons would be common is inconsistent with the deference required by Chenery $I I$.

164. See, e.g., Marcel, supra note 154, at 440 ; Sunstein, supra note 106 , at 183-84.

165. See supra notes 151-156 and accompanying text. Moreover, a Vermont Yankee-type remand may indirectly coerce the agency into providing an explanation for its decision and the methodology used to reach it. See, e.g., Byse, supra note 160, at 1827; Neely, supra note 160, at 285; Williams, supra note 163, at 454-55. Thus, Chief Judge Bazelon argued in his concurring opinion in the court of appeals decision in Vermont Yankee that agencies "should innovate procedural formats responsive to the new problems created by hybrid rulemaking." Natural Resources Defense Council, Inc. v. NRC, 547 F.2d 633, 656 (D.C. Cir. 1976), rev'd, 435 U.S. 519 (1978). One might therefore argue that heightened substantive scrutiny of agency decisions in order to facilitate use of remands for a more adequate statement of reasons would circumvent the holding in Vermont Yankee. Sec, e.g., Neely, supra note 160, at 308; Scalia, supra note 80, at 396-99. But see Byse, supra note 160, at 1827-29 (this type of traditional remand does not contravene Vermont Yankee). This problem is discussed further infra at notes 226-233 and accompanying text.

166. 371 U.S. 156 (1962).

167. Id. at 161 .

168. Id. at 168.

169. Id. 
the requirement in Burlington Truck Lines that the agency articulate a rational connection between the facts found and the choice made was merely a restatement of the proceduralist version of the reasons requirement.

As the Court retreated from proceduralism, however, it began to incorporate the Burlington Truck Lines "rational connection" language into the definition of the arbitrary and capricious standard of review. 170 This incorporation culminated in Motor Vehicle Manufacturers Association v. State Farm Mutual Automobile Insurance, ${ }^{171}$ in which the Court read prior decisions as establishing the reasons requirement as part of the arbitrary and capricious standard of review. Arbitrary and capricious was defined by employing the "rational connection" language from Burlington. ${ }^{172}$

The Court's application of the arbitrary and capricious standard of review in State Farm gave it new substantive content. The Court upheld that part of a court of appeals decision overturning the National Highway Traffic Safety Administration's (NHTSA) rescission of a regulation requiring manufacturers to install passive restraints-either airbags or automatic seatbelts. ${ }^{173}$ NHTSA based its rescission on the conclusion that, contrary to its original expectations, the rule would produce little or no benefit because virtually all manufacturers would install automatic seatbelts, which consumers would immediately detach. ${ }^{174}$ The Court's treatment of NHTSA's explanation revealed that the reasons requirement liad been given additional substantive content, i.e., that it had become a requirement that agencies give adequate reasons for their

170. See, e.g., Baltimore Gas and Elec. Co. v. Natural Resources Defense Council, Inc., 462 U.S. 87, 105 (1983); Bowman Transp., Inc. v. Arkansas-Best Freight Sys., Inc., 419 U.S. 281, 285 (1974). In Baltimore Gas, the Court engaged in substantive review of the zero-release assumption at issue in Vermont Yankee. In affirming the Nuclear Regulatory Commission, the Court stated: "It is not our task to determine what decision we, as Commissioners, would have reached. Our only task is to determine whether the Commission has considered the relevant factors and articulated a rational connection between the facts found and the choice made." 462 U.S. at 105. While this language tracks the language of Burlington Truck Lines, there is no discussion in Baltimore Gas of reasons as a procedural safeguard or as a basis for judicial review. Thus, the Burlington Truck Lines language had been completely separated from its original context in the proceduralist version of the reasons requirement.

171. 463 U.S. 29 (1983).

172. Id. at 43. Chenery $I$ was cited towards the end of this discussion, but only for the proposition that the Court "may not supply a reasoned basis for the agency's action that the agency itself has not given." Id. (quoting Chenery $D$. Thus, Chenery $I$ was depicted in State Farm as resting solely on the principle that courts should not intrude into the administrative process, and discussion of the necessity of reasons as a basis for judicial review was omitted.

173. Id. at 57. The Court vacated and remanded the case, noting that although it did not accept all the reasoning of the court of appeals, it did conclude that the National Highway Traffic Safety Agency failed to supply the "requisite reasoned analysis" in the case. Id.

174. Id. at 38-39. 
decisions. ${ }^{175}$

The Court found NHTSA's rescission of the regulation to be arbitrary and capricious because NHTSA failed to consider amending the regulation to require only airbags, even though it had acknowledged that their presence in automobiles would save many lives. ${ }^{176}$ Thus, NHTSA had violated the requirement "that an agency must cogently explain why it has exercised its discretion in a given manner."177 Even more illuminating is the Court's treatment of the regulation as it applied to automatic seatbelts. The agency had concluded that the evidence of safety benefits from automatic seatbelts was too inconclusive to support the regulation. According to the Court, the problem with NHTSA's decision was not the complete absence of reasons, but rather that the reasons given were "not sufficient to enable [the Court] to conclude that the rescission was the product of reasoned decisionmaking."178 In reaching this conclusion the Court engaged in an in-depth analysis of the reasoning offered by NHTSA. ${ }^{179}$

State Farm thus used the reasons requirement to engage in substantive review, which under the arbitrary and capricious standard became an inquiry into the adequacy of the reasons offered by the agency. The

175. We use the term "adequate reasons" to distinguish the requirement as applied in State Farm from the requirement as applied under structuralism or proceduralism. While the Court did not use this precise phrase, we believe it describes the type of review engaged in by the Court-the reasons given by the agency must be adequate in the sense that they must withstand substantive scrutiny by the courts. See id. at $48,52,56$. For a discussion of the elements of such scrutiny see infra notes 235-240 and accompanying text.

176. 463 U.S. at 48. The Court noted that " [there were] no findings and no analysis here to justify the ehoice made, no indication of the basis on which the [agency] exercised its expert discretion.' " Id. (quoting Burlington Truck Lines, 371 U.S. 156, 167 (1962)).

177. 463 U.S. at 48 (emphasis added). Although the proponents of the rescission offered various reasons to support the rejection of an airbags only requirement, the Court cited Chenery $I$ and refused to consider these objections because they had not been relied upon by the agency below. Id. at 50. This reasoning was consistent with the Court's limited reading of Chenery I. See supra note 172.

178. 463 U.S. at 52 (emphasis added).

179. The Court reasoned that NHTSA's reliance on nonuse of manual belts to conclude that automatic seatbelts would not be used failed to take account "of the critical difference between detachable automatic belts and current manual belts." Id. at 54 . Inertia would operate to increase usage of automatic belts because effort is required to detach them, whereas inertia operated against the use of manual belts, because effort is required to connect them. Thus it was arbitrary and capricious to rely on nonusage of manual belts to conclude that detachable belts would not be used. Moreover, NHTSA "failed to articulate a basis for not requiring nondetachable belts." Id. at 55 . In considering nondetachable belts, NHTSA had grouped continuous spool belts together with ignition interlock systems which prevented operation of a vehicle unless seatbelts were fastened, and rejected the nondetachable belt option because of widespread public reaction against ignition interlock systems. $I d$. at 55-56. Because continuous spool passive belts would not interfere with the operation of the vehicle, failure to consider that option separately was arbitrary and capricious, absent some "explanation why a continuous passive belt would engender the same adverse public reaction as the ignition interlock." Id. at 56. 
Court did not acknowledge the origins of the requirement as a structural safeguard under structuralism. Nor did the Court's discussion reflect the proceduralist conception of the requirement as protecting parties at the agency level and facilitatimg judicial review; that aspect of the requirement had been reduced to the principle that courts will not exercise the discretion Congress delegated to the agency.

\section{Separation of Powers, Rationalism, and the Reasons REQUIREMENT}

While State Farm marks the adoption of the rationalist model, with the requirement of adequate reasons as its central feature, the Court left the doctrinal basis of the requirement unclear. The rationalist model may best be understood as a form of heightened scrutiny of agency decisions required by separation of powers principles. This understanding accords with the history of the reasons requirement described above and left unexplored in State Farm. So articulated, the rationalist model preserves liberal values left unprotected following the demise of structuralism and the failure of proceduralism. In addition, the rationalist model accommodates progressive values better than either the structuralist or procedurahist models.

\section{A. Separation of Powers and the History of the Reasons Requirement.}

The reasons requirement is related to judicial review of the rationality of legislation. ${ }^{180}$ Such review normally is conducted under the extremely deferential "minimum rationality" test, which requires only that there be a conceivable rational basis for legislative acts. ${ }^{181}$ Scrutiny of the rationality of legislative purposes and means chosen to achieve them is heightened in some types of equal protection ${ }^{182}$ and substantive due process cases. ${ }^{183}$ The requirement of adequate reasons under the rationalist model entails a similar heightening of the scrutiny of agency

180. See Sunstein, supra note 12 , at 65 .

181. See L. TRIBE, supra note 37 , at $\S 16-3$ (discussing the conceivable basis test in equal protection analysis).

182. The level of scrutiny is heightened when legislation burdens a suspect class, see, e.g., Craig v. Boren, 429 U.S. 190 (1976) (intermediate scrutiny of legislation discriminating on the basis of gender); Loving v. Virginia, 388 U.S. 1 (1967) (strict scrutiny of legislation discriminating on the basis of race), or when allegedly discriminatory legislation burdens a fundamental right, see, e.g., Shapiro v. Thompson, 394 U.S. 618 (1969) (strict scrutiny of state denial of welfare benefits to new residents because denial burdened fundamental right to travel).

183. Modern strands of substantive due process sometimes involve heightened scrutiny of the purposes of legislation and the suitability of the legislative choice to the achievement of those purposes. See, e.g., Roe v. Wade, 410 U.S. 113 (1973). Before it was rejected, economic substantive due process also involved heightened scrutiny. See supra note 36 and accompanying text. 
decisions. ${ }^{184}$

In an early decision, Pacific States Box \& Basket Co. v. White, ${ }^{185}$ the Court equated agency and legislative action for purposes of the rational basis test, declaring that "if any state of facts reasonably can be conceived that would sustain [an order], there is a presumption of the existence of that state of facts."186 This is essentially identical to the rational basis test employed in judicial review of statutes that do not burden suspect classes or infringe upon fundamental rights. ${ }^{187}$ The subsequent evolution of the reasons requirement, however, evinces a gradual departure from minimum rationality review of agency decisions.

Minimum rationality review of agency decisions was appropriate under the structuralist model. Because agencies were perceived to be within the framework of separation of powers, Pacific States Box \& Bas$k e t$ 's analogy to decisions by the legislature was understandable. By connecting agency action to a narrow statutory mandate, the requirement placed the agency within the constitutional structure of separation of powers. ${ }^{188}$ Once the Court accepted delegations of legislative and judicial power to administrative agencies, however, this minimum rationality form of the requirement was inappropriate.

The reasons requirement became part of the procedural safeguards required by due process when the Court moved from structuralism to proceduralism as the means of protecting liberal values. ${ }^{189}$ In its proceduralist form, the reasons requirement accepted only those reasons offered by the agency in support of its decisions, rather than any conceivable state of facts as it did in Pacific States Box \& Basket. ${ }^{190}$ Nonethe-

184. In this article, the term "heightened scrutiny" is used in a generic sense to describe all levels of scrutiny stricter than the minimum rationality test. The specific level of heightened scrutiny applied to agency decisions is discusser in greater detail infra at notes 235-240 and accompanying text.

185. 296 U.S. 176 (1935).

186. Id. at 185. The Court explained:

Every exertion of the police power, either by the legislature or by an administrative body, is an exercise of delegated power. Where it is by statute, the legislature has acted under power delegated to it through the Constitution. Where the regulation is by an order of an administrative body, that body acts under a delegation from the legislature. ... [W] the regulation is within the scope of authority legally delegated, the presumption of the existence of facts justifying its specific exercise attaches alike to statutes, to municipal ordinances, and to orders of administrative bodies.

Id. at 185-86.

187. See R. PIERCE, S. Shapiro \& P. Verkuil, supra note $23, \S 7.3 .2$ (review of agency findings of fact); L. TRIBE, supra note 37 , at $\$ 16-3$ (equal protection review); see also supra note 37 and accompanying text (describing use of rational basis test as a result of the decline of structuralism).

188. See supra notes 129-130 and accompanying text.

189. See supra note 144 and accompanying text.

190. See supra note 141 and accompanying text. 
less, under proceduralism, once an agency gave reasons for its decision, the Court continued to accord it great deference.

When the proceduralist approach failed, the next logical step was to reject Pacific States Box \& Basket in its entirety and engage in heightened scrutiny of the adequacy of an agency's reasons. Thus, in State Farm the Court rejected the Department of Transportation's contention that the arbitrary and capricious standard was equivalent to the minimum rationality required of statutes, stating that "[w]e do not view as equivalent the presumption of constitutionahity afforded legislation drafted by Congress and the presumption of regularity afforded an agency in fulfilling its statutory mandate."191 State Farm left unclear the basis for heightened scrutiny of administrative decisions. The Court apparently derived the requirement of adequate reasons from the arbitrary and capricious standard of review under section 706 of the APA. ${ }^{192}$ State Farm and Pacific States Box \& Basket could therefore be reconciled by resting the heightened scrutiny approved in State Farm solely upon the requirements of the APA. ${ }^{193}$

The structuralist origins of the requirement, however, suggest that this reading of State Farm is mappropriate and that heightened scrutiny under the reasons requirement is best understood as a product of separation of powers. In its original minimum rationality form, the requirement furthered separation of powers primciples by ensuring agency

191. Motor Vehicle Mfrs. Ass'n v. State Farm Mut. Auto. Ins. Co., 463 U.S. 29, 43 n.9 (1983).

192. 5 U.S.C. $\$ 706(2)(A)(1982)$. The Court devoted considerable attention to identifying the arbitrary and capricious standard as the appropriate one for the rescission of a regulation, 463 U.S. - at 41-45, and it began its review of the rescission by stating that "[t]he ultimate question before us is whether [the] rescission of the passive restraint requirement . . . was arbitrary and capricious." Id. at 46. Most analyses of the State Farm decision have proceeded from the assumption that the Court was simply applying the arbitrary and capricious standard of review. See, e.g., Garland, supra note 151, at 512-13, 525-26; O'Reilly, Judicial Review of Agency Deregulation: Alternatives and Problems for the Courts, 37 VAND. L. REv. 509, 536-37 (1984); Note, Judicial Review of Informal Administrative Rulemaking, 1984 Duke L.J. 347, 366-69. This limited reading of State Farm is possible because under Bi-Metallic Inv. Co. v. State Bd. of Equalization, 239 U.S. 441, 445 (1915), due process safeguards do not apply when an agency legislates. See supra note 92 and accompanying text.

193. Another possible reconciliation of State Farm and Pacific States Box \& Basket would be to distinguish between review of federal administrative decisions, as in State Farm, and review of decisions by administrative agencies at the state level, as in Pacific States Box \& Basket. Similarly, review of decisions by state administrative agencies was involved in Southern Ry. v. Virginia, 290 U.S. 190 (1933); Bi-Metallic Inv. Co. v. State Bd. of Equalization, 239 U.S. 441 (1915); and Londoner v. Denver, 210 U.S. 373 (1908), where the Court considered whether additional procedural safeguards were required when an administrative agency, rather than a state legislature, acted. Such a distinction would be relevant because the separation of powers doctrine identified by structuralism is a matter of federal law only where federal agencies are concerned, or where a particular delegation at the state level offends due process. For a thorough analysis of the potential application of the nondelegation doctrine by federal courts to delegation of legislative power by states, see United Beverage Co. v. Indiana Alcoholic Beverage Comm'n, 760 F.2d 155, 157-60 (7th Cir. 1985). 
fidelity to narrow statutory mandates. To implement these principles in the face of broad delegations of legislative and judicial authority to administrative agencies, heightened judicial scrutiny is necessary.

Recently, in Bowen v. American Hospital Association, ${ }^{194}$ a plurality of the Supreme Court recognized the separation of powers aspects of heightened scrutiny under rationalism. Explaining the Court's rejection of minimum rationality in State Farm, the plurality stated that the "recognition of Congress' need to vest administrative agencies with ample power to assist in the difficult task of governing a vast and complex industrial Nation carries with it the correlative responsibility of the agency to explain the rationale and factual basis for its decision."195 While the Bowen plurality did not expressly rely on the separation of powers doctrine as a rationale for requiring adequate reasons, the decision does reflect an awareness that the adequate reasons requirement is integrally related to the structural dilemma inherent in the delegation of legislative and judicial power to administrative agencies. ${ }^{196}$

\section{B. Rationalism and Liberal Values.}

Understanding rationalism as a form of heightened scrutiny of administrative agencies required by separation of powers is consistent with both the history of the reasons requirement and recent Supreme Court decisions. So articulated, rationalism preserves liberal values better than either structuralism or proceduralism. First, rationalism protects liberal values on both a theoretical and a practical level through meaningful substantive scrutiny of agency actions. Second, the separation of powers basis for rationalism ensures that heightened scrutiny is available whenever an agency is delegated substantial legislative or judicial authority. ${ }^{197}$

194. 106 S. Ct. 2101 (1986) (plurality opinion).

195. Id. at 2113 .

196. See also International Union, UAW v. NLRB, 802 F.2d 969, 974 (7th Cir. 1986) (suggesting that agencies' combination of functions may be a reason that they are required to explain decisions).

197. For example, Congress could not require courts to employ minimum rationality review by repealing the APA. This result is desirable because the minimum rationality standard of review would leave agencies essentially unchecked. Neither structuralism nor proceduralism provided an effective mechanism for preventing administrative error and abuse. See supra notes 67-71, 94-98 and accompanying text. Of course, the Court could reinvigorate the separation of powers doctrine to severely limit agency government. This result might be more consistent with a strict reading of the Framers' intent, but is an unrealistic alternative because it would paralyze modern government.

Those who fear that judges will use heightened scrutiny to substitute their judgment for that of the agency could argue that repeal of the arbitrary and capricious standard of review may someday be necessary to prevent judges from thwarting Congress's regulatory policies. However, because rationalism tests the adequacy of an agency's reasons in terms of the purposes of a regulatory statute, Congress can prevent judicial obstruction by making those purposes clear. See infra notes 219-222 and accompanying text. 
1. Substantive Review and Liberal Values. A successful theory of judicial review must demonstrate that liberal values have not been sacrificed to accommodate administrative government. Rationalism meets that requirement by recognizing that agency action must be subjected to heightened scrutiny to ensure that administrative decisions reflect public values. Recent articles have argued that even if it is permissible for legislatures to compromise as a result of political pressure from interest groups, these compromises must be justifiable in terms of some identifiable public value, and that rationality review is the means of ensuring that this value exists. ${ }^{198}$ Others have forcefully challenged this view, arguing that judges should openly acknowledge and further legislative compromises rather than search for an illusory public value. ${ }^{199}$

Regardless of the merits of this debate as applied to judicial review of acts of Congress, it is clear that public value review is appropriate in the administrative context. ${ }^{200}$ As stated by the Court in State Farm ${ }^{201}$ and Bowen, ${ }^{202}$ administrative agencies, unlike legislatures, are not entitled to the same presumption of correctness because they are neither politically accountable nor directly subject to checks and balances. Unlike structuralism and proceduralism, rationalism protects liberal values at a theoretical level by recognizing that legislators and agency bureaucrats occupy different positions in our scheme of government and therefore must be treated differently for purposes of judicial review.

For a consideration of rationalism's implications for preclusion of review, see infra notes 205210 and accompanying text.

198. See Macey, supra note 34, at 262 (use of legislative histories to gain justification for interpretation of statute will lead to a lessening of special interest litigation if courts reject interpretations not based upon public interest); Sunstein, supra note 12, at $43-45$ (role of court is to check interest group factionalism in legislature); Sunstein, supra note 34, at 1694-95 ("Few statutes fail rationality review. This phenomenon raises the question whether the Court's commitment to the prohibition of naked preferences, as exemplified by the existence of rationality review, is merely rhetorical."); see also Diver, supra note 121, at 423-24 (incrementalism contrary to ability of agency to comprehend full range of interests affected by its decisions); cf. Fiss, Forward: The Forms of Justice, 93 HARv. L. REv. 1, 2 (1979) (judicial review of legislation should enforce public values implicit in the Constitution).

199. See, e.g., Posner, supra note 73, at 285 (arguing rationality review is inconsistent with acceptance of interest groups' influence on legislative process); Easterbrook, supra note 34, at 14-18, 60 ("Judges' claim to authority rests on a plausible demonstration that they are faithfully executing decisions made by others."). For a response, see Sunstein, Factions, Self Interest and the APA: Four Lessons Since 1946, 72 VA. L. REv. 271, 282 n.59 (1986) (arguing for greater judicial scrutiny).

200. The commentators generally have not addressed the distinction between legislation by Congress and decisions by agencies. See supra note 198. As a consequence they have not articulated a constitutional basis for heightened scrutiny of agency decisions. See, e.g. Sunstein, supra note 12, at 64-66 (recognizing that the uneasy constitutional position of administrative agencies has led to more rigorous application of rationality review, but assuming that it is a product of statutory interpretation or federal common law).

201. See supra note 191 and accompanying text.

202. See supra note 195 and accompanying text. 
The protection of liberal values requires as a practical matter that judicial review act as a meaningful check on administrative error and abuse. Rationalism provicles an effective mechanism of judicial review because it addresses the practical problem that structuralism and proceduralism could not solve. Review under the structuralist model ultimately failed because courts could not determine from a simple articulation of facts whether an agency was operating within its broad and vague statutory mandate. ${ }^{203}$ Proceduralism attempted to address this difficulty by requiring agencies to connect their decisions with facts in the record through a statement of reasons. This approach failed because tlie deferential treatment accorded to an agency's reasons enabled an agency to support virtually any decision with selective facts plucked from a large and univieldy record. ${ }^{204}$ By comparison, rationalism places the burden on an agency to adequately explain its decision in terms of its statutory mandate. In order to obtain judicial approval, agencies must be able to demonstrate that they have applied their expertise in a meaningful manner and have reasonably investigated the problem they are attempting to resolve.

2. The Availability of Review. Requiring adequate reasons cannot protect liberal values on eitler a theoretical or practical level if judicial review is unavailable. Thus, rationalism implies that separation of powers requires judicial review to be available whenever an agency exercises substantial legislative or judicial functions. The Court has never squarely addressed this issue, despite intimations in some cases that a general presumption of reviewability is a constitutional requirement. ${ }^{205}$ While some cases deny judicial review because of congressional preclusion, ${ }^{206}$ or on prudential grounds, ${ }^{207}$ these cases generally involve agency exercise of ministerial or executive functions. ${ }^{208}$ To the extent that these or other cases suggest Congress's ability to preclude review of the exercise of legislative or judicial power by agencies, we would argue that they are

203. See supra text accompanying note 130 .

204. See supra notes $145-147$ and accompanying text.

205. See supra note 88 and accompanying text.

206. Sec, c.g., Heckler v. Chaney, 470 U.S. $821,832-33$ (1985) (FDA refusal to take enforcement action unreviewable); Panama Canal Co. v. Grace Line, Inc., 356 U.S. 309 (1958) (decision on rates for use of Panama Canal unreviewable); Dalehite v. United States, 346 U.S. 15 (1953) (decisions concerning shipping methods for foreign aid goods unreviewable); Langevin v. Chenango Court, Inc., 447 F.2d 296 (2d Cir. 1971) (FHA decision to allow rent increase for public housing unreviewable); Hahn v. Gottlieb, 430 F.2d 1243 (1st Cir. 1970) (same).

207. See, e.g., Schonbrun v. Comınanding Officer, 403 F.2d 371, 374-75 (2d Cir. 1968) (military personnel decisions unreviewable), cert. denied, 394 U.S. 929 (1969).

208. Block v. Community Nutrition Inst., 467 U.S. 340 (1984), which held that consumers were precluded from seeking reviev of DO.4 orders regarding milk prices, is distinguishable because handlers were entitled to seek review. 
wrongly decided. The APA exceptions to the availability of judicial review ${ }^{209}$ should be construed narrowly. ${ }^{210}$

Whether judicial review of the reasons for an agency decision is constitutionally required depends not upon due process, but rather upon separation of powers. This conclusion has several important implications for rationalism. First, it means that the availability of review does not depend upon the existence of a liberty or property interest protected by due process. ${ }^{211}$ Second, unlike procedural due process protections, the requirement of review is not limited to adjudications by agencies. ${ }^{212}$ Thus, rationalism avoids one of the fundamental theoretical failures of proceduralism: it protects liberal values in all cases where agencies exercise powers otherwise preserved for the legislature or the judiciary. Finally, rationalism would not require federal review of decisions by state administrative agencies because separation of powers at the state level is a matter of state law. ${ }^{213}$

209. 5 U.S.C. $\$ 701$ (a) (1982). The APA exceptions apply when judicial review is precluded by statute, 5 U.S.C. $\S 701$ (a)(1) (1982), or where a decision is committed to agency discretion by law, 5 U.S.C. $\$ 701(\mathrm{a})(2)(1982)$.

210. Cf. Johnson v. Robison, 415 U.S. $361,366-74$ (1974) (statutory preclusion of review does not preclude review of constitutional issues). In a recent study of preclusion of judicial review of agency rulemaking, Professor Verkuil concludes that judicial review of the "substantive rationality" of rules is constitutionally required. Verkuil, Congressional Limitations on Judicial Review of Rules, 57 TUL. L. Rev. 733, 746-53 (1983). Professor Verkuil suggests that the minimum rationality standard of Pacific States Box \& Basket Co. v. White, 296 U.S. 176, 185-86 (1935), is appropriate for this review, and that heightened scrutiny is required only by the APA. See Verkuil, supra, at 747-48. This article argues, however, that heightened scrutiny of agency decisions is required by the unique constitutional position of administrative agencies. See supra notes 180-197 and accompanying text.

211. The scope of the "liberty" and "property" interests protected by due process has been the subject of considerable litigation and commentary. See, e.g., Cleveland Bd. of Educ. v. Loudermill, 470 U.S. 532 (1985); Ingraham v. Wright, 430 U.S. 651 (1977); Paul v. Davis, 424 U.S. 693 (1976); Goss v. Lopez, 419 U.S. 565 (1975); Aruett v. Kennedy, 416 U.S. 134 (1974); Perry v. Sindermann, 408 U.S. 593 (1972); Board of Regents v. Roth, 408 U.S. 564 (1972); 2 K. DAVIS, supra note 160, at \$ 11.14; Herman, The New Liberty: The Procedural Due Process Rights of Prisoners and Others Under the Burger Court, 59 N.Y.U. L. Rev. 482 (1984); Reich, The New Property, 73 YALE L.J. 733 (1964); Van Alstyne, Cracks in "The New Property": Adjudicative Due Process in the Administrative State, 62 Cornell L. Rev. 445 (1977); Williams, Liberty and Property: The Problem of Government Benefits, 12 J. LEG. STUD. 3 (1983). The authors take no position in this article regarding the appropriate scope of interests protected by due process.

212. See supra note 92 and accompanying text.

213. Despite earlier Supreme Court precedent, e.g. Wichita R.R. \& Light Co. v. Public Utils. Comm'n, 260 U.S. 49, 58-59 (1922) (diversity case applying the nondelegation doctrine to require a statement of necessary facts by a state agency), recent cases have abandoned any suggestion that separation of powers at the state level is a matter of federal concern. See United Beverage Co. v. Indiana Alcoholic Beverage Comm'n, 760 F.2d 155, 157-59 (7th Cir. 1985) (no federal doctrine limiting state legislature's delegation of powers to state agency). The authors do not mean to suggest that the reasons requirement must be totally severed from its procedural connotations; insofar as a statement of reasons is required by procedural due process it remains a federal issue. See supra note 144. 


\section{Rationalism and Progressive Values.}

While rationalism preserves liberal values, it also accommodates progressive values because heightened scrutiny of the rationality of agency decisions is consistent with the underlying purposes of agency government. Administrative agencies were premised upon the Progressives' belief that regulatory decisions should be the product of rational bureaucratic processes or the dispassionate application of expertise. ${ }^{214}$ By focusing on the reasoning used to justify an agency decision rather than the result of the decision, rationalism reinforces this progressive ideal without granting judges a license to substitute their judgment for that of the agency. ${ }^{215}$ Thus, unlike structurahism and proceduralism, use of the rationalist model by activist courts should not thwart progressive government. ${ }^{216}$

Critics of the rationalist model can argue that it is subject to similar abuses and that it is no better equipped to find an appropriate middle ground between disruption of admimistrative government and abandonment of any meaningful effort to control administrative discretion. This criticism may occur at three levels. First, the use of heightened substantive scrutiny arguably invites the same sort of judicial intervention which characterized substantive due process. Second, because of the close connection between the requirement of adequate reasons and the procedures used to generate support for those reasons, employing the rationalist

\footnotetext{
214. See supra notes 16-22 and accompanying text.

215. This distinction may explain the otherwise apparently irreconcilable Supreme Court decisions in Baltimore Gas \& Elec. Co. v. Natural Resources Defense Council, Inc., 462 U.S. 87 (1983) and Motor Vehicle Mfrs. Ass'n v. State Farm Mut. Auto. Ins. Co., 463 U.S. 29 (1983). While Baltimore Gas is generally viewed as an example of extreme deference to an administrative agency, see, e.g., Stever, Deference to Administrative Agencies in Federal Environmental, Health and Safety Litigation-Thouglits on Varying Judicial Application of the Rule, 6 W. NEW ENG. L. REv. 35, 5859 (1983); Note, The Vermont Yankee Line: A Hard Look Becomes a Passing Glance, 19 NEw ENG. L. REv. 837, 860.63 (1984), State Farm has been almost uniformly interpreted as staking out a more aggressive posture' of judicial review. See, e.g., Edwards, Judicial Review of Deregulation, 11 N. KY. L. REv. 229, 253-55 (1984); Garland, supra note 151, at 545-49. In Baltimore Gas, however, the Supreme Court reversed a court of appeals decision which focused not on the adequacy of the reasons supporting an agency decision, but rather on the wisdom of that decision itself. See Natural Resources Defense Council, Inc. v. NRC, 685 F.2d 459, 494 (D.C. Cir. 1982), rev'd, 462 U.S. 87 (1983). The Court emphasized that "[i]t is not our task to determine what decision we, as Commissioners, would have reached." 462 U.S. at 105 . In State Farm, on the other hand, the Court approved heightened scrutiny of the reasoning used by an agency to justify its decision, while recognizing that the courts are not to substitute their judgment for that of the agency. 463 U.S. 29, 43-44 (1983).

216. The use of substantive due process and the nondelegation doctrine within the structuralist model blocked progressive government by invalidating legislation necessary to implement progressive values. See supra notes 36-38 and accompanying text. Likewise, the insistence on additional procedures under the proceduralist model destroyed administrative efficiency and threatened to bring progressive government to a grinding halt. See supra notes 96-98 and accompanying text.
} 
model could destroy administrative efficiency. Finally, substantive scrutiny of agency decisions may lead to the substitution of the policy preferences for those of agencies, in contravention of the progressive premise of administrative expertise.

1. Substantive Due Process. Because rationalism requires heightened scrutiny of the rationahity of agency action, critics might associate it with the heightened scrutiny of legislative decisions under substantive due process. Early Supreme Court decisions striking down legislation under economic substantive due process, and more recent decisions striking down state regulation interfering with individual autonomy, have been criticized as undemocratic intervention by the Court in contravention of the will of the majority. 217

This criticism reflects the underlying tension between competing elements of liberal values incorporated into the Constitution. ${ }^{218}$ The legislature is a pluralistic institution implementing the principle of government by consent, while judicial review reflects the republican principles of limited government and separation of powers. ${ }^{219}$ Those who condemn judicial activism in the form of substantive due process are in effect arguing that it promotes republican values at the expense of pluralistic values, thereby upsetting the compromise envisioned by the Framers of the Constitution. Moreover, substantive due process often entails judicial intervention to enforce principles not expressly contained in the Constitution, which is seen as a particularly dangerous invitation to judges to inpose their will on the majority. 220

While similar objections might be raised against heightened scrutiny of agency decisions under rationalism, they do not apply. Unlike substantive due process, rationalism does not place constitutional limitations on the ability of Congress to legislate. If a court reverses an agency for

217. See, e.g., McClosky, supra note 36 , at 44 (policy and value judgments are best left to the people and their representatives). For an opposing viewpoint, see L. TRIBE, ConstirutionaL CHOICES 3-44 (1985) (advocating judicial review to promote constitutional values). For a discussion of the controversy surrounding the modern use of substantive due process to protect rights of privacy and autonomy see, G. GunTHER, Constirutional LAw 501-66 (11th ed. 1985).

218. See supra notes 8-12 and accompanying text.

219. See, e.g., Sunstein, supra note 34 , at 1691.

220. In his dissent to Thornburgh v. American College of Obstetricians and Gynecologists, 106 S. Ct. 2169 (1986), Justice White warned:

When the Court ventures further and defines as "fundamental" liberties that are nowhere mentioned in the Constitution (or that are present only in the so-called "penumbras" of specifically enumerated rights), it must, of necessity, act with more caution, lest it open itself to the accusation that, in the name of identifying constitutional principles to which the people have consented in framing their Constitution, the Court has done nothing more than impose its own controversial choices of value upon the people.

Id. at 2194 (White, J., dissenting). See generally Bork, Neutral Principles and Some First Amendment Problems, 47 IND. L.J. 1 (1971) (arguing for judicial restraint). 
the failure to explain adequately how its decision serves its statutory mission, Congress is free to overrule that decision. The legislature can expressly authorize the agency's decision by amending the agency's enabling act. Moreover, rationalism assists the legislature in any necessary correction. It can foster informed political dialogue by forcing agencies to articulate the basis for their policies. ${ }^{221}$ Nor does heightened scrutiny of agency decisions involve the enforcement of unwritten principles and the consequent invitation to judges to impose their value preferences by invalidating agency action. The primciples to be enforced under rationalism are those in the statute authorizing agency action. Thus, the proper role of statutory interpretation under rationalism is to identify the value choice embodied in a statute. Identification of values obviously must occur if judicial review is to ensure a rational relationship between agency action and the statutory objectives. ${ }^{222}$

It might be argued, however, that heightened scrutiny involves stricter judicial oversight of executive action insofar as agencies are part of the executive branch. ${ }^{223}$ According to this objection, heightened scrutiny would constitute an undesirable limitation on the President, who is, unlike federal judges, an elected official.224 This objection, however, fails to recognize that the Framers did not envision that executive branch agencies would be authorized by Congress to exercise extensive legislative and judicial powers. ${ }^{225}$ Thus, heightened scrutiny actually serves the

221. See Diver, supra note 121 , at 414 .

222. This role for statutory interpretation is preferable to use of statutory interpretation to narrow the scope of agency authority as the principal mechanism to control administrative discretion. See supra notes 67-71 and accompanying text.

223. Justice Rehnquist argued in State Farm that "[a] change in administration brought about by the people casting their votes is a perfectly reasonable basis for an executive agency's reappraisal of the costs and benefits of its programs and regulations." 463 U.S. 29, 59 (1983) (Rehnquist, J., concurring in part and dissenting in part). This argument reflects the assumption that agencies are responsive to the electoral process-an assumption to some degree at odds with the progressive conception of agencies as removed from politics so that they may apply their expertise dispassionately. See supra note 17 and accompanying text. Agencies are at best indirectly accountable to the political process. See Pierce \& Shapiro, supra note 103, at 1200-03. Justice Rehnquist recognized this problem in another context, where he argued that agencies are not sufficiently politically accountable to make "important choices of social policy" which can only be decided by Congress, "the branch of our Government most responsive to the popular will." Industrial Union Dep't v. American Petroleum Inst., 448 U.S. 607, 685 (1980) (Rehnquist, J., concurring) (arguing for application of the nondelegation doctrine to strike down the Oecupational Safety and Health Act). Whether or not Justice Rehnquist's apparently conflicting assumptions about the political accountability of administrative agencies are reconcilable, agencies do not occupy the same position as Congress for the purposes of balancing pluralistic and republican values.

224. See Pierce, supra note 33 , at 520-23.

225. See supra note 65 and accompanying text. Judge Posner has suggested that the application of the adequate reasons requirement to executive agencies in State Farm is inconsistent with a separation of powers basis for the requirement. International Union, UAW v. NLRB, 802 F.2d 969, 974 (7th Cir. 1986). However, this suggestion fails to appreciate that the exercise of legislative and 
balance of pluralism and republicanism struck by the Framers because it creates a necessary judicial check on expanded executive power.

2. Rationalism and Procedural Inefficiency. During the period of judicial imposition of hybrid procedures, courts and commentators acknowledged that judicial decisions remanding a decision to an agency for more support might indirectly require the agency to engage in additional procedures which the Vermont Yankee decision had forbidden courts to impose directly. ${ }^{226}$ Thus, critics might argue that heightened scrutiny of the rationality of agency decisions would destroy admimistrative efficiency by indirectly requiring additional procedures. This criticism is, however, unpersuasive because remands for more adequate reasons allow the agency to determine whether and to what degree additional procedures will be followed.

Three possible situations may be involved when an agency decision is remanded for lack of adequate reasons. First, there may be an easily remedied flaw in the agency's logic or a gap in its reasoning process. ${ }^{227}$ In such a case, the agency on reinand need not engage in any additional procedures to correct this flaw. ${ }^{228}$ Second, an agency may be required to provide additional factual support for its decision, which might lead to additional proceedings pursuant to the APA. ${ }^{229}$ Fimally, in rare cases the agency may be unable to elicit adequate support for its reasoning without engaging in some form of hybrid procedures. ${ }^{230}$

judicial functions by executive agencies is as inconsistent with a strict reading of the separation of powers doctrine as is the creation of independent agencies to exercise those functions.

226. See supra note 165 .

227. See, e.g., Eastern Carolinas Broadcasting Co. v. FCC, 762 F.2d 95 (D.C. Cir. 1985) (arbitrary invocation of $\S 402(\mathrm{~h})$ of the Communications Act of 1934 to reject portions of plaintiff's supplemental filing cured by agency's finding existing record sufficient to analyze plaintiff's claim).

228. Because courts will engage in heightened scrutiny of an agency's reasoning under rationalism, it is possible that the additional reasoning supplied by an agency will not withstand review. However, if no reasoning can be found to support an agency's decision, then judicial rejection of that decision is appropriate.

229. See, e.g., Motor Vehicle Mfrs. Ass'n v. EPA, 768 F.2d 385 (D.C. Cir. 1985) (where statute requires EPA to determine that fuel will not cause failure of emission device, EPA must clearly find basis for determining that back-to-back testing provides adequate and sufficient means of evaluating 50,000 miles of actual driving); Trailways Lines, Inc. v. ICC, 766 F.2d 1537, 1544 n.13 (D.C. Cir. 1985) (Commission must consider long range effects on industry but court cannot order ICC to investigate in any particular manner).

230. For example, in some cases an agency may rely on what Professor Davis has called "judicial" facts. 1 K. Davis, Administrative Law Treatise $\$ 7.02$ (1958). See United Air Lines, Inc. v. CAB, 766 F.2d 1107, 1119 (Tth Cir. 1985) ("[P]rovided that the agency issues what is genuinely a rule ... it is free to base the rule on the kinds of findings normally made in an adjudicative proceeding, even if it conducts no evidentiary hearing."). The regulations in question in United Air Lines had been based on an administrative finding that certain airlines, which provided computerized reservation services to travel agents, had abused their market power over an essential facility. While the court exhibited some reluctance in upholding the regulations based on "adjudicative 
Given these divergent possibilities, a significant benefit of rationalism is that the agency determines what additional procedures, if any, are appropriate. ${ }^{231}$ Because on remand agencies are free to narrowly tailor any additional procedures to the inadequacies of their reasons, this form of remand ensures that any additional procedures will improve the decision of the agency. While rationalism may lead agencies to engage in more extensive reasoning in run-of-the-mill cases to avoid reversal, this change is desirable insofar as it protects liberal values and ensures that agencies apply their expertise consistently with progressive values. This reasoning need not be overly elaborate or involve formal procedures because the agency's explanation must only be "adequate." Efforts to define this standard, beginning with State Farm, will help to ensure that heightened scrutiny will not bog down the administrative process. ${ }^{232}$ Thus, rationalism avoids the problems identified in Vermont Yankee. ${ }^{233}$

3. Rationalism and Expertise. The foregoing criticisms of rationalism are similar to the problems which led to the demise of structuralism and proceduralism. A third criticism, unique to rationalism, is that heightened substantive review will undercut deference to administrative expertise. Unlike structuralism and proceduralism, rationalism invites judges to scrutinize the substantive aspects of an agency's decision. This heightened scrutiny of substance, some commentators argue, will invite judges to substitute their policy preferences for those of an agency. According to these critics, judges have used and will use heightened scrutiny as a subterfuge to impose their own substantive viewpoints. ${ }^{234} \mathrm{We}$ believe, however, that refinement of the rationalist model will minimize this difficulty.

Both the Supreme Court and legal commentators are currently engaged in an effort to define the requirement of adequate reasons in a comprehensive manner. At one time, particularly after Citizens to Preserve

factfindings" made in the course of a rulemaking proceeding, it felt compelled by precedent to uphold them. Id. at 1118. However, the court indicated that although pertinent authority precluded judicial imposition of trial-type procedures in the case before it, presumably "there would be an exception for a fact that could not rationally be found without providing an opportunity for crossexamination or some other trial-type procedural safeguard." Id. at 1119. See also Shapiro, supra note 96 (arguing that some disputed matters of scientific fact would be illuminated by adjudicatory procedures).

231. See Byse, supra note 160 , at 1829-32 (legislative history indicates that whether additional procedural devices are to be employed is an agency question because agency is best able to take into account considerations of practicality and necessity).

232. See infra notes $238-240$ and accompanying text.

233. 435 U.S. $519,546-47$ (1978). See supra notes $157-160$ and accompanying text.

234. See, e.g., O'Brien, Marbury, The APA, and Science-Policy Disputes: The Alluring and Elusive Judicial/Administrative Partnership, 7 Harv. J.L. \& PUB. Pol. 443, 480-81 (1984); Pierce, supra note 33, at 504-07. 
Overton Park, Inc. v. Volpe, ${ }^{235}$ the adequate reasons requirement was the subject of considerable confusion. The Court described a reviewing court's scope of review as "whether the decision was based on a consideration of the relevant factors and whether there has been a clear error of judgment."236 This formulation, with its open-ended phrasing concerning "relevant factors," invited judges to establish their own standards of what an agency should consider in order to produce an adequately reasoned decision. ${ }^{237}$ Further, the "clear error of judgment" language invited judges to consider the result reached by an agency, rather than its reasons.

In State Farm, the Court helped to resolve this confusion by adopting a more exact definition of the adequate reasons requirement. The Court said the requirement includes a determination of whether an agency relied on factors that Congress had not intended it to consider, whether it failed to consider "entirely" an important aspect of the problem it was resolving, and whether it offered an explanation for its decision that ran counter to the evidence or was so implausible that it could not be explained as a product of a difference in view or of agency expertise. ${ }^{238}$

State Farm makes clear that the proper focus for review is not the result reached by an agency, but rather the reasons given to support that result. This distinction is important because it reminds judges that they are not to substitute their judgment for the policy choices of an agency and that the agency's reasoning may withstand scrutiny even if a judge

235. 401 U.S. 402 (1971).

236. Id. at 416.

237. See Levin, Federal Scope-of-Review Standards: A Preliminary Restatement, 37 AD. L. REv. 95, 109-10 (1985).

238. 463 U.S. 29, 43 (1983). Further, the Court warned that it would " "uphold a decision of less than ideal clarity if the agency's path may reasonably be discerned." Id. (quoting Bowman Transp., Inc. v. Arkansas-Best Freight Sys., Inc., 419 U.S. 281, 285 (1974)).

A recent report for the American Bar Association synthesizing the case law applying the requirement of adequate reasons has continued the process of defining the scope of substantive review. See Levin, supra note 234. Professor Levin's report on "Federal Scope-of-Review" standards, which was prepared for the ABA Section of Administrative Law, includes a hypothetical revision of the scope of review section of the APA, that requires a court to set aside agency action if it finds that: (1) the agency "has relied on considerations that may not be taken into account under, or has ignored considerations that must be taken into account under" relevant statutes and other sources of law; (2) "[t]he action embodies an egregious error of judgment"; (3) "[t]he action embodies an egregious error of logic"; (4) "[t]he asserted or necessary factual premises of the action do not withstand scrutiny under" the appropriate scope of review; or (5) "[t]he action is unjustifiably inconsistent with prior agency policies or practices." Id. at 99. The report recognizes, but does not endorse, a standard apparently applied by some courts that agency action should be set aside if it is the "product of irresponsibly superficial decisionmaking." Id. 
disagrees with the result. ${ }^{239}$ Moreover, the focus on an agency's reasoning allows judges to acknowledge agency expertise where appropriate. ${ }^{240}$

It would, of course, be naive to suppose that rationalism can completely avoid the problem of judges finding flaws in agency reasoning because they dislike the result. ${ }^{241}$ However, the heightened scrutiny endorsed by State Farm has not led to excessive reversal rates. ${ }^{242}$ Regardless of the model employed, a judge can always find error on which a reversal may be based, especially in comphicated cases with involved records. ${ }^{243}$ To the extent that intervention does occur under rationalism,

239. Cf, supra note 215 (reconciling State Farm with Baltimore Gas). Although the Court in State Farm did quote the confusing "clear error of judgment" language from Overton Park, 463 U.S. at 43 , the remainder of the discussion makes clear that whether an "error" has occurred is to be determined from the agency's reasoning rather than based on the reviewing court's assessment of the result.

240. Thus, State Farm indicated that an agency explanation was to be rejected only if it was so implausable that it could not be attributed to agency expertise. Id.

241. See Friendly, supra note 160, at 224 (reviewing court "is more likely to take a charitable view toward error in subsidiary findings when it sympathizes with the agency's end result than when it does not"); see also Rodgers, Judicial Review of Risk Assessments: The Role of Decision Theory in Unscrambling the Benzene Decision, 11 ENVTL. L. 301, 302 (1981) ("[T] se suspicion has arisen, certainly among practitioners who can say such things, that the grand synthesizing principle that tells us whether the court will dig deeply or bow cursorily depends exclusively on whether the judge agrees with the result of the administrative decision.").

242. The rate of reversal of administrative decisions by circuit courts of appeals has not been affected by the endorsement of heightened scrutiny by the State Farm decision in 1983:

$\begin{array}{llllll}\text { Year: } & \frac{1982}{12.6} & \frac{1983}{11.1} & \frac{1984}{12.0} & \frac{1985}{11.2} & \frac{1986}{11.5}\end{array}$

Reversal rates are taken from the ANNIJAL RePORT OF THE DiRECTOR OF THE ADMINISTRATIVE OfFICE OF THE UNITED STATES CoUR'TS (1982-1986) (Table B1 for years 1982-1984; Table B5 for years 1985-1986). This rate reflects a substantial decline from the previously predominant rate of reversal:

$\begin{array}{llllll}\text { Year: } & \frac{1961}{23.6} & \frac{1966}{22.2} & \frac{1971}{17.4} & \frac{1976}{19.1} & \frac{1981}{20.5}\end{array}$

See id. (1961, 1966, 1971, 1976, \& 1981) (Table B1). In our survey, see Appendix, courts reversed agency decisions for substantive inadequacy in 46 cases, about $26 \%$ of the 177 cases in the survey and $30 \%$ of the cases in which substantive inadequacy was argued. This figure is greater than the overall reversal rate because agency action is often affirmed without a published opinion. See R. PIERCE, S. SHAPIRo \& P. VeRKUIL, supra note $23, \S 7.8$, at 378 (reporting results of study undertaken by Judge Wald of District of Columbia Circuit cases). Such affirmances would not be included ill our survey base.

Garland, supra note 151, at 549, suggests that since State Farm, courts have been more active in using the arbitrary and capricious standard of review to strike down agency action. Because the overall reversal rate remained constant, however, any increase must refiect a shift from the use of other grounds for reversal. To the extent this conclusion is correct, it reflects an advantage of the rationalist model, because rationalism is less disruptive of the administrative process than reversal under the structuralist or proceduralist models. See infra notes 244-245 and accompanying text.

243. Professor Tushnet has argued that it is impossible to devise a system of judicial review of legislation which both allows the judiciary to strike down legislation, and places some limits on their 
its consequences are less severe than the consequences of intervention under the structuralist or proceduralist model. Under structuralism, judicial intervention involves either the invalidation of an agency's statute or a narrowing construction of that statute, both of which have farreaching consequences. ${ }^{244}$ In contrast, intervention under the rationalist model would be case specific. Similarly, the form of remedy required by judicial intervention under procedurahism destroyed administrative efficiency. As indicated above, however, the inpact of remands under rationalism is not so severe. ${ }^{245}$

Although the Court's efforts to define judicial review under rationalism nnake review less open-ended, there will still be some variation in the scope of review. Factors such as the type of problem the agency is resolving, a court's assessinent of the special expertise of an agency in a problem area, and the court's comprehension of that problem, will necessarily influence the degree of deference accorded to agency decisions. ${ }^{246}$ This variability, however, is not only unavoidable, it is appropriate. The type of discretion exercised in progressive government varies remarkably from agency to agency and froin function to function. ${ }^{247}$ The accommodation of progressive and liberal values, therefore, will require different comproinises in different contexts. ${ }^{248}$

capacity to do so. For a summary of this argument see, Tushnet, Judicial Review, 7 HARV. J.L. \& PuB. Pol. 77, 77 (1984). A similar argument might be applied to judicial review of agency decisions. Even if this argument is true, it is not a reason to reject rationalism. The consequences of judicial intervention under rationalism are less severe than intervention under structuralism or proceduralism. See infra text accompanying note 244 . The alteruative of eliminating judicial review of agencies would leave them entirely without legitimation.

244. See supra notes $67-71$ and accompanying text.

245. See supra notes $226-233$ and accompanying text.

246. See A.B.A. Sec. Ad. L., National Institute on Federal Agencies and the Public Interest, Panel IV: Judicial Review of Agency Action, 26 AD. L. REv. 545, 575 (1974) (remarks of Judge Oakes) (degree of deference varies with character of agency, nature of problems, extent to which review interferes with agency's functions, nature of the procedures used, and other factors); DeLong, New Wine for a New Bottle: Judicial Review in the Regulatory State, 72 VA. L. REv. 399, 400 (1986) (variations in agency form and function require varied mechanisms of control); Kaufman, Judicial Review of Agency Action: A Judge's Unburdening, 45 N.Y.U. L. REv. 201, 209 (1970) (reviewing courts are influenced by instinctive feelings conceruing the "bona fides of the parties" or their sense that "justice" is not being done).

247. See Shapiro, Administrative Discretion: The Next Stage, 92 YALE L.J. 1487, 1500 (1983) (typography of administrative discretion).

248. Although the courts usually do not articulate the basis on which these accomodations are made, recent scholarly efforts have begun to show how such an articulation may occur. See, e.g., Diver, supra note 121, at 428-34 (discussing judicial balancing of competing models of "comprehensive rationalism" and "incrementalism"); Shapiro, supra note 247, at 1512 (discussion of agency alternatives to rule-making and adjudication, such as negotiation, mediation, and arbitration, as means of regulation and policy enforcement). 


\section{CONCLUSION}

The struggle to devise a successful theory of judicial review of administrative action is as old as administrative law itself. Other means of controlling administrative agencies exist, but only the Supreme Court has the opportunity to explain how agencies fit within our constitutional framework so as to accommodate liberal and progressive values on both a theoretical and practical level. The recent emergence of rationalism, which focuses on substantive review of the rationality of agency decisions, is a promising approach to judicial review-if understood as a requirement of separation of powers.

Rationalist review acknowledges the unique constitutional position of agencies outside of the tripartite system of government envisioned by the Framers, and compensates through heightened scrutiny of agency decisions in the form of the requirement that agencies give adequate reasons. Such an understanding of the reasons requirement is preferable to the common assumption that the requirement is solely a product of the APA's arbitrary and capricious standard of review. That assumption implies that heightened scrutiny is subject to legislative repeal, and robs the model of its potential to legitimate administrative government at the constitutional level.

When rationalism is understood as a matter of separation of powers, it provides a theory of judicial review which successfully accommodates liberal and progressive values. Rationalism promotes liberal values by explaining how agencies, which exist as a fourth branch of government, fit within our constitutional system. By imposing heightened scrutiny under separation of powers principles, rationalism establishes judicial review of agency action as an effective check on agency action. Rationalism serves progressive values as well. Progressives wish to solve social problems by delegating broad discretion to expert decisionmakers. Recognition that the progressive ideal of neutral application of expertise to solve complex social problems reflected unrealistic assumptions about bureaucratic behavior only underscores the need for substantive review of agency decisions. By requiring the agency to explain its decision in terms of the progressive values embodied in its statutory mandate, rationalist review ensures the application of expertise and prevents undue influence by special interests, without excessively impairing the agency's ability to implement that statutory mandate.

\section{APPENDIX}

To examine the application of the rationalist model in practice, we conducted a Westlaw search of decisions by United States Circuit Courts 
of Appeals involving judicial review of administrative decisions (either directly, through review of district court opinions reviewing agency action, or in private litigation in which one of the parties challenged agency determination). The search retrieved court of appeals cases from certain "key numbers" within the subject heading "Administrative Law and Procedure" 249 for the period from January 1, 1984 through December 31,1985 . The search was designed to produce a broad sampling of cases which, though not sufficiently reliable to allow derivation of empirically accurate statistics, would nonetheless be representative and allow some general conclusions. The search retrieved a total of 193 cases, of which 16 have been eliminated from the sample because they did not involve issues relevant to this analysis. ${ }^{250}$ Although some of the remaining 177 cases involved review of decisions of state administrative agencies, the vast majority involved review of federal agencies.

The results of the survey are summarized at the end of this appendix in a table which breaks down the cases according to the treatment of arguments typically made under the three models discussed in this article: statutory interpretation as a reflection of structuralism, ${ }^{251}$ procedural objections as a reflection of proceduralism, ${ }^{252}$ and the lack of adequate reasons as a reflection of rationalism. ${ }^{253}$ We determined whether each argument was not raised, raised unsuccessfully, or raised

249. The key numbers used in the search were: $391,485,651,676,741,750-764,781,784-800$, and 819.

250. Farley Transp. Co. v. Sante Fe Trail Transp. Co., 778 F.2d 1365 (9th Cir. 1985); Department of Energy v. Brimmer, 776 F.2d 1554 (Temp. Emer. Ct. App. 1985), cert. denied, 106 S. Ct. 1261 (1986); Ruff v. Hodel, 770 F.2d 839 (9th Cir. 1985); Rodriguez v. Donovan, 769 F.2d 1344 (9th Cir. 1985); Quincy Cable TV, Inc. v. FCC, 768 F.2d 1434 (D.C. Cir. 1985), cert. denied, 106 S. Ct. 2889 (1986); Florida Dep't of Business Regulation v. Department of Interior, 768 F.2d 1248 (1lth Cir. 1985), cert. denied, 475 U.S. 1011 (1986); Baltimore Gas \& Elec. Co. v. Heintz, 760 F.2d 1408 (4th Cir.), cert. denied, 475 U.S. 847 (1985); Philip Morris, Inc. v. Block, 755 F.2d 368 (4th Cir. 1985); Air Line Pilots Ass'n Int'l v. CAB, 750 F.2d 81 (D.C. Cir. 1984); Walter O. Boswell Memorial Hosp. v. Heckler, 749 F.2d 788 (D.C. Cir. 1984); Zook v. Brown, 748 F.2d 1161 (7th Cir. 1984); International Union, UAW v. Donovan, 746 F.2d 855 (D.C. Cir. 1984), cert. denied, 474 U.S. 825 (1985); Council of Prison Locals v. Brewer, 735 F.2d 1497 (D.C. Cir. 1984); South Carolina Elec. \& Gas Co. v. ICC, 734 F.2d 1541 (D.C. Cir. 1984); Jean v. Nelson, 727 F.2d 957 (11th Cir. 1984), aff'd, 472 U.S. 846 (1985); Sayles v. Welborn, 725 F.2d 436 (7th Cir. 1984).

251. See supra notes 35-64 and accompanying text. The table does not refiect arguments as to the constitutionality of a particular agency based on restriction of powers or separation of powers arguments because such arguments were extremely rare.

252. See supra notes $72-88$ and accompanying text.

253. See supra notes 100-123 and accompanying text. All arguments concerning substantive review of agency decisions were treated in this category, including those focusing on substantial evidence review, or those applying the arbitrary and capricious standard of review without explicit reference to the reasons requirement. 
successfully. ${ }^{254}$ Characterizing arguments as belonging to one of these groups was, as with all legal characterizations, not without difficulty, ${ }^{255}$ but the survey reflects certain trends so strongly that any disagreement as to the appropriate characterization of a few cases should not detract from the conclusions drawn from the survey.

\section{TABLE 4}

\begin{tabular}{|c|c|c|c|c|c|c|c|c|c|}
\hline & \multicolumn{3}{|c|}{$\begin{array}{c}\text { STATUTORY } \\
\text { INTERPRETATION } \\
\end{array}$} & \multicolumn{3}{|c|}{ PROCEDURES } & \multicolumn{3}{|c|}{ REASONS } \\
\hline & $\begin{array}{l}\text { Not } \\
\text { Arg. }\end{array}$ & $\begin{array}{l}\text { Arg. } \\
\text { Lost } \\
\end{array}$ & $\begin{array}{l}\text { Arg. } \\
\text { Won }\end{array}$ & $\begin{array}{l}\text { Not } \\
\text { Arg. }\end{array}$ & $\begin{array}{l}\text { Arg. } \\
\text { Lost } \\
\end{array}$ & $\begin{array}{l}\text { Arg. } \\
\text { Won } \\
\end{array}$ & $\begin{array}{l}\text { Not } \\
\text { Arg. }\end{array}$ & $\begin{array}{l}\text { Arg. } \\
\text { Lost } \\
\end{array}$ & $\begin{array}{l}\text { Arg. } \\
\text { Won } \\
\end{array}$ \\
\hline TOTAL: & 95 & 61 & 21 & 122 & 47 & 8 & 26 & 105 & 46 \\
\hline NAME: & & & & & & & & & \\
\hline $\begin{array}{l}\text { ACEMLA v. } \\
\text { Copyright Royalty } \\
\text { Tribunal }\end{array}$ & & & $x$ & $\mathbf{x}$ & & & $x$ & & \\
\hline $\begin{array}{l}\text { AFL-CIO y. } \\
\text { Donovan }^{257}\end{array}$ & & $\mathrm{x}$ & & & & $\mathrm{x}$ & & $\mathrm{x}$ & \\
\hline $\begin{array}{l}\text { Air Pollution Control } \\
\text { Dist. v. EPA }\end{array}$ & & $x$ & & & $x$ & & & $\mathrm{x}$ & \\
\hline $\begin{array}{l}\text { Airmark Corp. v. } \\
\text { FAA }^{259}\end{array}$ & & $\mathrm{x}$ & & $x$ & & & & & $x$ \\
\hline $\begin{array}{l}\text { American Fin. Servs. } \\
\text { Ass'n v. FTC } 260\end{array}$ & & $\mathrm{x}$ & & $\mathrm{x}$ & & & & $\mathrm{x}$ & \\
\hline $\begin{array}{l}\text { American Mining } \\
\text { Congress } y_{\text {. }} \\
\text { Thomas } 261\end{array}$ & & & $\mathrm{x}$ & $x$ & & & & $x$ & \\
\hline $\begin{array}{l}\text { American Tunaboat } \\
\text { Ass'n v. Baldrige } 262\end{array}$ & $x$ & & & $x$ & & & & & $x$ \\
\hline
\end{tabular}

254. We treated arguments as not raised if the court did not discuss them. We considered arguments as successful if the court rejected any part of the agency's decision in question, even though other parts of the agency's decision were left intact.

255. For example, it was sometimes impossible to separate procedural objections from objections as to the adequacy of the reasons given. See, e.g., Thompson v. Clark, 741 F.2d 401 (D.C. Cir. 1984); Arkla Exploration Co. v. Texas; Oil \& Gas Corp., 734 F.2d 347 (8th Cir. 1984), cert. denied, 469 U.S. 1158 (1985). In other cases, it was difficult to determine whether an argument was based upon statutory interpretation or the adequacy of reasons. See, e.g., Motor Vehicle Mfrs. Ass'n v. EPA, 768 F.2d 385 (D.C. Cir. 1985), cert. denied, 474 U.S. 1082 (1986); Prill v. NLRB, 755 F.2d 941 (D.C. Cir.), cert, denied, 474 U.S. 948 (1985); Dimension Fin. Corp. v. Board of Governors, 744 F.2d 1402 (10th Cir. 1984), aff'd, 474 U.S. 361 (1986). Finally, in some instances procedural issues were discussed as a matter of statutory interpretation. See, e.g., Bethlehem Steel Corp. v. Gorsuch, 742 F.2d 1028 (7th Cir. 1984).

256. 763 F.2d 101 (2d Cir. 1985).

257. 757 F.2d 330 (D.C. Cir. 1985).

258. 739 F.2d 1071 (6th Cir. 1984).

259. 758 F.2d 685 (D.C. Cir. 1985).

260. 767 F.2d 957 (D.C. Cir. 1985).

261. 772 F.2d 617 (10th Cir. 1985), cert denied, 106 S. Ct. 2275 (1986).

262. 738 F.2d 1013 (9th Cir. 1984). 
TABLE 4 (Continued)

STATUTORY

\section{INTERPRETATION}

Not Arg. Arg.

Arg. Lost Won

\section{PROCEDURES}

Not Arg. Arg.

Arg. Lost Won

\section{REASONS}

Not Arg. Arg.

Arg. Lost Won

Arizona Pub. Serv.

Co. v. United

States $^{263}$

$\mathbf{x}$

Arkansas Power \& Light Co. v. ICC 264

Arkla Exploration Co. v. Texas Oil \& Gas Corp. 265 $\mathbf{x}$ $\mathbf{x}$ $x$

Army Eng'r Center v. Federal Labor Relations Auth. 266 Asarco, Inc. v. OSHA 267

Asbestos Information Ass'n/North America v. OSHA 268

Association of Data

Processing Serv. Orgs. Inc. v. Board of

Governors 269

$\mathrm{x}$

$\mathrm{x}$

$\mathrm{x}$

Bacon v. Department of Hous. and Urban Dev. 270

Baker v. Heckler 271

Barajas v. Heckler 272

$\mathbf{x}$

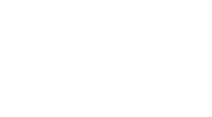

Bass v. Department of Agric. 273

$\mathbf{x}$

$\mathrm{x}$

$\mathbf{x}$

$\mathrm{x}$

$x$

$\mathrm{x}$

$\mathbf{x}$

$\mathbf{x}$

$\mathbf{x}$

Baylor Univ. Medical Center v. Heckler ${ }^{274}$

Beardmore v.

Department of Agric. $^{275}$

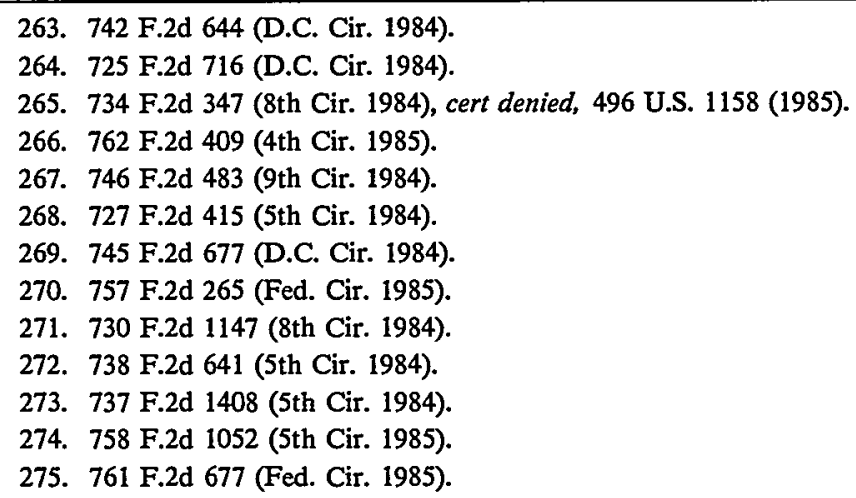


TABLE 4 (Continued)

STATUTORY

INTERPRETATION

PROCEDURES

REASONS

Not Arg. Arg.

Arg. Lost Won

Not Arg. Arg.

Arg. Lost Won Arg. Lost Won

Bedford County Gen. Hosp. v. Heckler ${ }^{276}$

Bedford County

Memorial Hosp. v.

Health and Human

Servs. 277

$x$

$x$

$x$

Beerly v. Department

$x$

$x$ of Treasury 278

Bender v. Clark 279

$\mathbf{x}$

$\mathrm{x}$

$\mathbf{x}$

$x$

$\mathrm{x}$

Brickner v. FDIC 282

California ex rel Van

De Kamp v. Tahoe

Regional Planning

Agency ${ }^{283}$

CWT Farms, Inc. v.

$\mathrm{CIR}^{284}$

Carstens v. NRC 285

Center for Auto

Safety v. Peck 286

Central \& Southern

Motor Freight Tariff

Ass'n v. United

States $^{287}$

Chocolate Mfrs. Ass'n v. Block 288

Cities of Campbell v. FERC $^{289}$

276. 757 F.2d 87 (6th Cir. 1985).

277. 769 F.2d 1017 (4th Cir. 1985).

278. 768 F.2d 942 (7th Cir. 1985), ccrt. denied, 475 U.S. 1010 (1986).

279. 744 F.2d 1424 (10th Cir. 1984).

280. 742 F.2d 1028 (7th Cir. 1984).

281. 754 F.2d 804 (9th Cir. 1984).

282. 747 F.2d 1198 (8th Cir. 1984).

283. 766 F.2d 1308 (9th Cir. 1985).

284. 755 F.2d 790 (11th Cir. 1985), cert. denied, 106 S. Ct. 3271 (1986).

285. 742 F.2d 1546 (D.C. Cir. 1984), eert. denied, 471 U.S. 1136 (1985).

286. 751 F.2d 1336 (D.C. Cir. 1985).

287. 757 F.2d 301 (D.C. Cir.), cert. denied, 474 U.S. 1019 (1985).

288. 755 F.2d 1098 (4th Cir. 1985).

289. 770 F.2d 1180 (D.C. Cir. 1985). 
TABLE 4 (Continued)

\begin{tabular}{|c|c|c|c|c|c|c|c|c|}
\hline \multicolumn{3}{|c|}{$\begin{array}{l}\text { STATUTORY } \\
\text { INTERPRETATION }\end{array}$} & \multicolumn{3}{|c|}{ PROCEDURES } & \multicolumn{3}{|c|}{ REASONS } \\
\hline Not & Arg. & Arg. & Not & Arg. & Arg. & Not & Arg. & Arg \\
\hline Arg. & Lost & Won & Arg. & Lost & Won & Arg. & Lost & Wor \\
\hline
\end{tabular}

Cities of Carlisle and Neola v. FERC 290

Citizens State Bank v. FDIC $^{291}$

City of Angels

Broadcasting, Inc. v. FCC $^{292}$

City of Charlottesville v. FERC ${ }^{293}$

City of Long Beach v. Department of Energy 294

City of New York

Mun. Broadcasting Sys. v. FCC 295

City of Pompano

Beach v. FAA 296

Coleman v. United

States Secret Serv. 297

Community Nutrition Inst. v. Young 298

Consolidated Gas

Transmission Corp. v. FERC 299

Consumer Prods.

Div., SCM Corp. v. Silver Reed Am., Inc. 300

Contact Lens Mfrs.

Ass'n v. FDA ${ }^{301}$

Containerfreight

Corp. v. United

States 302

290. 741 F.2d 429 (D.C. Cir. 1984)

291. 751 F.2d 209 (8th Cir. 1984).

292. 745 F.2d 656 (D.C. Cir. 1984).

293. 774 F.2d 1205 (D.C. Cir. 1985), cert. denied, 106 S. Ct. 1515 (1986).

294. 754 F.2d 379 (Temp. Emer. Ct. App. 1985).

295. 744 F.2d 827 (D.C. Cir. 1984), cert. denied, 470 U.S. 1084 (1985).

296. 774 F.2d 1529 (11th Cir. 1985).

297. 749 F.2d 726 (Fed. Cir. 1984).

298. 773 F.2d 1356 (D.C. Cir. 1985), cert. denied, 106 S. Ct. 1642 (1986).

299. 771 F.2d 1536 (D.C. Cir. 1985).

300. 753 F.2d 1033 (Fed. Cir. 1985).

301. 766 F.2d 592 (D.C. Cir. 1985), cert. denied, 474 U.S. 1062 (1986).

302. 752 F.2d 419 (9th Cir. 1985). 


\section{TABLE 4 (Continued)}

STATUTORY INTERPRETATION

\section{PROCEDURES}

Not Arg. Arg. Not Arg. Arg. Arg. Lost Won Arg. Lost Won

Cook v. Heckler ${ }^{303}$

Corning Sav. \& Loan

Ass'n v. Federal

Home Loan Bank

Bd. 304

Cranston v. Clark ${ }^{305}$

DeSarno v.

Department of Commerce 306

Del Norte County v. United States ${ }^{307}$

Department of Educ. v. Bell ${ }^{308}$

Department of Labor v. Kast Metals

Corp. ${ }^{309}$

\begin{tabular}{lll}
\hline Not Arg. Arg. \\
Arg. Iost Won \\
\hline
\end{tabular}

$\mathrm{x}$

$x$

$\mathrm{x}$

$\mathbf{x}$

$\mathrm{x}$

$\mathrm{x}$

$\mathrm{x}$

$\mathrm{x}$

$\mathbf{x}$

$\mathbf{x}$

$\mathrm{x}$

x

$\mathrm{x}$

Desoto Gen. Hosp. v. Heckler $^{310}$

Detroit, T.\&I.R.R. v. United States 311

Deukmejian v.

$\mathrm{NRC}^{312}$

Dill v. INS ${ }^{313}$

Dimension Fin. Corp.

v. Board of

Governors $^{314}$

Donovan v. A.A.

Beiro Const. Co., Inc. $^{315}$

Donovan v. Adams

Steel Erection,

Inc. 316

303. 750 F.2d 391 (5th Cir. 1985).

304. 736 F.2d 479 (8th Cir. 1984).

305. 767 F.2d 1319 (9th Cir. 1985).

306. 761 F.2d 657 (Fed. Cir. 1985).

307. 732 F.2d 1462 (9th Cir. 1984), cert. denied, 469 U.S. 1189 (1985).

308. 770 F.2d 1409 (9th Cir. 1985).

309. 744 F.2d 1145 (5th Cir. 1984).

310. 766 F.2d 182 (5th Cir. 1985).

311. 725 F.2d 47 (6th Cir. 1984).

312. 751 F.2d 1287 (D.C. Cir. 1984).

313. 773 F.2d 25 (3d Cir. 1985).

314. 744 F.2d 1402 (10th' Cir, 1984), aff'd, 474 U.S. 361 (1986).

315. 746 F.2d 894 (D.C. Cir. 1984).

316. 766 F.2d 804 (3d Cir. 1985). 
TABLE 4 (Continued)

STATUTORY

INTERPRETATION PROCEDURES REASONS

Not Arg. Arg. Not Arg. Arg. Not Arg. Arg.

Arg. Lost Won

Arg. Lost Won Arg. Lost Won

Dugan v. Ramsay 317

Duke Power Co. v.

$\mathrm{NRC}^{318}$

Eagle-Picher Indus. v. EPA $^{319}$

$\mathbf{x}$

$\mathbf{x}$

$\mathrm{x}$

$x$

$\mathbf{x}$

Eastern Carolinas

Broadcasting Co. v.

FCC $^{320}$

Electricity Consumers

Resource Council v.

FERC ${ }^{321}$

Enos v. Marsh 322

Erickson Air Crane

Co. v. United

States $^{323}$

Erickson Transp.

Corp. v. $\mathrm{ICC}^{324}$

Exxon Corp v.

Department of

Energy $^{325}$

Farmer's Union Cent.

Exch., Inc. v.

FERC 326

Florida Fruit \&

Vegetable Ass'n v.

Brock $^{327}$

Fremont-Madison

Irrigation Dist. v.

Department of

Interior 328

Frisby v. Department of Hous. and Urban Dev. ${ }^{329}$

$\mathbf{x}$

$\mathbf{x}$

$x$

$\mathbf{x}$

$\mathrm{x}$

x

x

x

x

X

$\mathrm{x}$

x $\mathrm{x}$

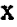

$\mathbf{x}$

$x$

$x$

x

X

x

x

X

$\mathrm{x}$

317. 727 F.2d 192 (1st Cir. 1984).

318. 770 F.2d 386 (4th Cir. 1985).

319. 759 F.2d 905 (D.C. Cir. 1985).

320. 762 F.2d 95 (D.C. Cir. 1985).

321. 747 F.2d 1511 (D.C. Cir. 1984) (per curiam).

322. 769 F.2d 1363 (9th Cir. 1985).

323. 731 F.2d 810 (Fed. Cir. 1984).

324. 728 F.2d 1057 (8th Cir. 1984).

325. 752 F.2d 650 (Temp. Emer. Ct. App. 1984).

326. 734 F.2d 1486 (D.C. Cir.), cert. denied, 469 U.S. 1034 (1984).

327. 771 F.2d 1455 (11th Cir. 1985).

328. 763 F.2d 1084 (9th Cir. 1985).

329. 755 F.2d 1052 (3d Cir. 1985). 
TABLE 4 (Continued)

STATUTORY INTERPRETATION

\section{PROCEDURES}

Not Arg. Arg. Arg. Lost Won
Garrett v. Lehman 330

General Elec. Co. v. $\mathrm{NRC}^{331}$

General Motors Corp. v. Ruckelshaus ${ }^{332}$

Gilbert v, Burlington Indus. ${ }^{333}$

Green County Mobilephone, Inc. v. FCC 334

\begin{tabular}{ccc} 
Not & Arg. & Arg. \\
Arg. & Lost & Won \\
\hline
\end{tabular}

$\mathrm{x}$

$\mathrm{x}$

\section{$\mathrm{x}$}

$\mathrm{x}$ $\mathbf{x}$

$\mathrm{x}$

$\mathrm{x}$

$x$

Greenwood Utils.

Comm'n v. Hodel ${ }^{335}$

Griessenauer v.

Department of

Energy 336

Hameetman v. City of Chicago 337

Hudson Transit Lines, Inc. v. ICC ${ }^{338}$

Humana of Aurora, Inc. v. Heckler ${ }^{339}$

ITT Worid

Communications, Inc. v. $\mathrm{FCC}^{340}$

Illinois Bell Tel. Co. v. $\mathrm{FCC}^{341}$

International Union of Operating Eng'rs v. NLRB $^{342}$

Iowa State Commerce Comm'n v. Federal Inspector of Alaska Natural Gas Transp.

\section{REASONS}

Not Arg. Arg.

Arg. Lost Won

$\mathrm{x}$

$\mathrm{x}$

$\mathbf{x}$

$\mathrm{x}$ $x$

$\mathrm{x}$

$\mathrm{x}$

$x$

$\mathrm{x}$

$\mathrm{x}$

$x$

$\mathrm{x}$

$\mathbf{x}$

$x$

$\mathrm{x}$

$x$

$\mathrm{x}$

$x$

$\mathrm{x}$

$x$

$x$

$\mathrm{x}$

$x$

\footnotetext{
330. 751 F.2d 997 (9th Cir. 1985).

331. 750 F.2d 1394 (7th Cir. 1984).

332. 742 F.2d 1561 (D.C. Cir. 1984), cert. denied, 471 U.S. 1074 (1985).

333. 765 F.2d 320 (2d Cir. 1985), aff'd, 106 S. Ct. 3267 (1986).

334. 765 F.2d 235 (D.C. Cir. 1985).

335. 764 F.2d 1459 (1Ith Cir. 1985).

336. 754 F.2d 361 (Fed. Cir. 1985).

337. 776 F.2d 636 (7th Cir. 1985).

338. 765 F.2d 329 (2d Cir. 1985).

339. 753 F.2d 1579 (10th Cir.), cert. denied, 474 U.S. 863 (1985).

340. 725 F.2d 732 (D.C. Cir. 1984).

341. 740 F.2d 465 (7th Cir. 1984).

342. 755 F.2d 78 (7th Cir. 1985).
} 
TABLE 4 (Continued)

STATUTORY

INTERPRETATION

PROCEDURES

REASONS

Not Arg. Arg. Not Arg. Arg. Not Arg. Arg. Arg. Lost Won Arg. Lost Won Arg. Lost Won

Sys. ${ }^{343}$

$\mathrm{x}$

$x$

Donovan $^{344}$

KVK Partnership v. Hodel $^{345}$

Kaho v. Ilchert ${ }^{346}$

$\mathrm{x}$

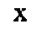

$\mathrm{x}$

Krispy Kreme

Doughnut Corp. v. NLRB $^{347}$

Kunaknana v.

Clark $^{348}$

Kwan v. Donovan 349

Laipenieks v. INS ${ }^{350}$

Local One,

Amalgamated

Lithographers v.

NLRB ${ }^{351}$

M.M. \& P. Maritime

Advancement,

Training, Educ. \&

Safety Program

(MATES) v.

Department of

Commerce 352

MCI

Telecommunications

Corp. v. FCC 353

Mackowiak v.

University Nuclear

Sys., Inc. 354

Maine v. Department

of Labor ${ }^{355}$ $\mathbf{x}$

$\mathbf{x}$

$\mathrm{x}$

$\mathrm{x}$

$\mathbf{x}$

$\mathbf{x}$

$\mathrm{x}$

$\mathbf{x}$

$\mathbf{x}$

343. 730 F.2d 1566 (D.C. Cir. 1984).

344. 758 F.2d 1313 (9th Cir. 1984).

345. 759 F.2d 814 (10th Cir. 1985).

346. 765 F.2d 877 (9th Cir. 1985).

347. 732 F.2d 1288 (6th Cir. 1984).

348. 742 F.2d 1145 (9th Cir. 1984).

349. 777 F.2d 479 (9th Cir. 1985).

350. 750 F.2d 1427 (9th Cir. 1985).

351. 729 F.2d 172 (2d Cir. 1984).

352. 729 F.2d 748 (Fed. Cir. 1984).

353. 750 F.2d 135 (D.C. Cir. 1984).

354. 735 F.2d 1159 (9th Cir. 1984).

355. 770 F.2d 236 (1st Cir. 1985). 


\section{TABLE 4 (Continued)}

\begin{tabular}{|c|c|c|c|c|c|c|c|c|}
\hline \multicolumn{3}{|c|}{$\begin{array}{l}\text { STATUTORY } \\
\text { INTERPRETATION }\end{array}$} & \multicolumn{3}{|c|}{ PROCEDURES } & \multicolumn{3}{|c|}{ REASONS } \\
\hline $\begin{array}{l}\text { Not } \\
\text { Arg. }\end{array}$ & $\begin{array}{l}\text { Arg. } \\
\text { Lost }\end{array}$ & $\begin{array}{l}\text { Arg. } \\
\text { Won }\end{array}$ & $\begin{array}{l}\text { Not } \\
\text { Arg. }\end{array}$ & $\begin{array}{l}\text { Arg. } \\
\text { Lost }\end{array}$ & $\begin{array}{l}\text { Arg. } \\
\text { Won }\end{array}$ & $\begin{array}{l}\text { Not } \\
\text { Arg. }\end{array}$ & $\begin{array}{l}\text { Arg. } \\
\text { Lost }\end{array}$ & $\begin{array}{l}\text { Arg. } \\
\text { Won }\end{array}$ \\
\hline
\end{tabular}

Markair, Inc. v.

\section{$\mathrm{CAB}^{356}$}

Maryland Dept. of

Human Resources v.

Department of Health and Human Servs. ${ }^{357}$

Maryland People's

Counsel v. FERC ${ }^{358}$

Maryland Wildlife

Fed'n v. Dole 359

Melamine Chems.,

Inc. v. United

States 360

Memorial Hosp. v.

Heckler ${ }^{361}$

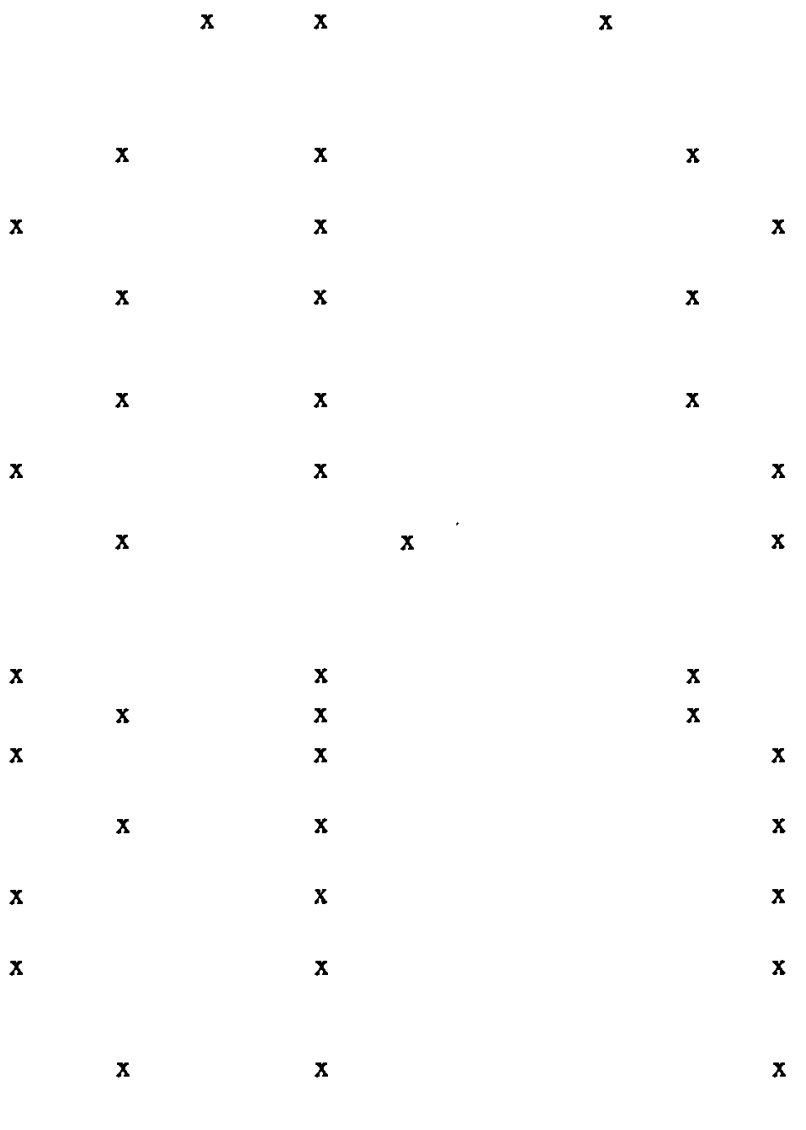

Mid-Tex Elec, Coop.

v. FERC ${ }^{362}$

Moapa Band of

Paiute Indians $v$.

Department of

Interior $^{363}$

Moore v. Custis ${ }^{364}$

Moret v. $\mathrm{Karn}^{365}$

Motor Vehicle Mfrs.

Ass'n v. EPA ${ }^{366}$

NLRB v. Norbar,

Inc. $^{367}$

Nagi y. United

States $^{368}$

National Ass'n of

Regulatory Util.

Comm'rs v. FCC ${ }^{369}$

\footnotetext{
356. 744 F.2d 1383 (9th Cir. 1984).

357. 763 F.2d 1441 (D.C. Cir. 1985).

358. 761 F.2d 780 (D.C. Cir. 1985).

359. 747 F.2d 229 (4th Cir. 1984).

360. 732 F.2d 924 (Fed. Cir. 1984).

361. 760 F.2d 771 (7th Cir. 1985).

362. 773 F.2d 327 (D.C. Cir. 1985).

363. 747 F.2d 563 (9th Cir. 1984).

364. 736 F.2d 1260 (8th Cir. 1984).

365. 746 F.2d 989 (3d Cir. 1984).

366. 768 F.2d 385 (D.C. Cir. 1985), cert. denied, 474 U.S. 1082 (1986).

367. 752 F.2d 235 (6th Cir. 1985).

368. 751 F.2d 826 (6th Cir. 1985).

369. 737 F.2d 1095 (D.C. Cir. 1984), cert. denied, 469 U.S. 1227(1985).
} 
TABLE 4 (Continued)

STATUTORY

INTERPRETATION PROCEDURES

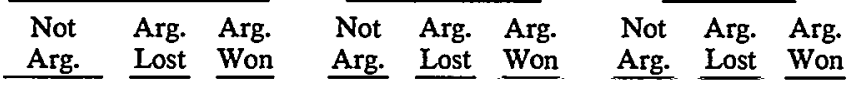

National Cattlemen's

Ass'n v. EPA ${ }^{370}$

$\mathbf{x}$

$\mathbf{x}$

National Classification

Comms. v. United

States $^{371}$

$\mathbf{x}$

$\mathbf{x}$

$\mathbf{x}$

National Fed. of Fed.

Employees, Local

1669 v. Federal Labor

Relations Auth. 372

National Small

Shipments Traffic

Conference, Inc. v.

$\mathrm{ICC}^{373}$

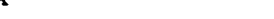

Natural Resources

Defense Council, Inc.

v. Herrington 374

Neighborhood T.V.

Co. v. FCC 375

New York Council,

Ass'n of Civilian

Technicians v. Federal

Labor Relations

Auth. ${ }^{376}$

$\mathrm{x}$

$x$

$\mathrm{x}$

$\mathbf{x}$

$x$

New York State

Comm'n on Cable

Television v. FCC ${ }^{377}$

New York Urban

Coalition, Inc. v.

Department of

Labor $^{378}$

North Carolina

Comm'n of Indian

Affairs v. Department

of Labor 379

Ohio v.

Ruckelshaus 380 $\mathrm{x}$

$\mathrm{x}$ $\mathbf{x}$

$x$

$\mathbf{x}$

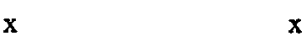

$x$

$\mathbf{x}$

$\mathbf{x}$

370. 773 F.2d 268 (10th Cir. 1985).

371. 765 F.2d 1146 (D.C. Cir. 1985).

372. 745 F.2d 705 (D.C. Cir. 1984).

373. 725 F.2d 1442 (D.C. Cir. 1984).

374. 768 F.2d 1355 (D.C. Cir. 1985).

375. 742 F.2d 629 (D.C. Cir. 1984).

376. 757 F.2d 502 (2d Cir.), cert. denied, 474 U.S. 846 (1985).

377. 749 F.2d 804 (D.C. Cir. 1984).

378. 731 F.2d 1024 (2d Cir. 1984).

379. 725 F.2d 238 (4th Cir.), cert. denied, 469 U.S. 828 (1984).

380. 776 F.2d 1333 (6th Cir. 1985), cert. denied, 106 S. Ct. 2889 (1986). 


\section{TA.BLE 4 (Continued)}

\begin{tabular}{|c|c|c|c|c|c|c|c|c|}
\hline \multicolumn{3}{|c|}{$\begin{array}{l}\text { STATUTORY } \\
\text { INTERPIRETATION }\end{array}$} & \multicolumn{3}{|c|}{ PROCEDURES } & \multicolumn{3}{|c|}{ REASONS } \\
\hline $\begin{array}{l}\text { Not } \\
\text { Arg. }\end{array}$ & $\begin{array}{l}\text { Arg. } \\
\text { Lost }\end{array}$ & $\begin{array}{l}\text { Arg. } \\
\text { Won }\end{array}$ & $\begin{array}{l}\text { Not } \\
\text { Arg. }\end{array}$ & $\begin{array}{l}\text { Arg. } \\
\text { Lost }\end{array}$ & $\begin{array}{l}\text { Arg. } \\
\text { Won }\end{array}$ & $\begin{array}{l}\text { Not } \\
\text { Arg. }\end{array}$ & $\begin{array}{l}\text { Arg. } \\
\text { Lost }\end{array}$ & $\begin{array}{l}\text { Arg. } \\
\text { Won }\end{array}$ \\
\hline
\end{tabular}

Onslow County v.

Department of

Labor $^{381}$

$\mathbf{x}$

Organized Fishermen v. Hodel ${ }^{382}$

Orleans Audubon

Soc'y v. Lee ${ }^{383}$

Owens v. Heckler ${ }^{384}$

Owens v. National

Transp. Safety Bd. ${ }^{385}$

Panhandle Coop.

Ass'n v. EPA 386

Paralyzed Veterans v. $\mathrm{CAB}^{387}$

Pennsylvania Pub.

Util. Comm'n v.

United States 388

Petrou Fisheries, Inc.

v. ICC 389

Petry v. Block ${ }^{390}$

Pfizer, Inc. v.

Heckler ${ }^{39 i}$

Pinar v. Dole 392

Pollgreen v.

Morris 393

Presinzano v.

Hoffman-La Roche, Inc. 394

Prill v. NLRB ${ }^{395}$

$\mathrm{x}$

$\mathrm{x}$

$x$

$x$

$\mathbf{x}$

$\mathrm{x}$
$\mathrm{x}$
$\mathrm{x}$
$\mathrm{x}$
$\mathrm{x}$

$\mathrm{x}$

$\mathrm{x}$

$\mathbf{x}$

$\mathrm{x}$

$\mathrm{x}$

$\mathrm{x} \quad \mathrm{x}$

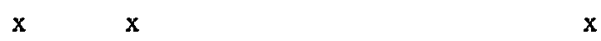

$\mathrm{x}$ $\mathbf{x}$

$\mathrm{x}$

\section{$x$}

$x$

$\mathbf{x}$

$\mathrm{x}$

$\mathrm{x}$

$\mathbf{x}$

$\mathbf{x}$

$\mathbf{x}$

$\mathbf{x}$

$x$

381. 774 F.2d 607 (4th Cir. 1985).

382. 775 F.2d 1544 (11th Cir. 1985), cert. denied, 106 S. Ct. 2890 (1986).

383. 742 F.2d 901 (5th Cir. 1984).

384. 748 F.2d 1511 (11th Cir. 1984).

385. 734 F.2d 396 (8th Cir. 1984).

386. 771 F.2d 1149 (8th Cir. 1985).

387. 752 F.2d 694 (D.C. Cir. 1985), rev'd, 474 U.S. 918 (1986).

388. 749 F.2d 84 I (D.C. Cir. 1984).

389. 727 F.2d 542 (5th Cir. 1984).

390. 737 F.2d 1193 (D.C. Cir. 1984).

391. 735 F.2d 1502 (D.C. Cir. 1984).

392. 747 F.2d 899 (4th Cir. 1984), cert. denied, 471 U.S. 1016 (1985).

393. 770 F.2d 1536 (11th Cir. 1985).

394. 726 F.2d 105 (3d Cir. 1984).

395. 755 F.2d 941 (D.C. Cir.), cert. denied, 474 U.S. 948 (1985). 
TABLE 4 (Continued)

STATUTORY

$\frac{\text { INTERPRETATION }}{\text { Not Arg. Arg. Not Arg. Arg. Not Arg. Arg. }}$

Arg. Lost Won Arg. Lost Won Arg. Lost Won

Pupillo v. United States 396

$x$

$x$

EPA $^{397}$

RSR Corp. $y$.

Donovan $^{398}$

Robertson v. Dean

Witter Reynolds,

Inc. 399

Sears Sav. Bank v.

FSLIC ${ }^{400}$

Shoreham Coop.

Apple Producers

Ass'n, Inc. v.

Donovan 401

Sierra Club v. United

States Army Corps of

Eng'rs ${ }^{402}$

Sierra Club v.

Clark $^{403}$

Sierra Club v.

Clark $^{404}$

Southern Cal. Edison

Co. v. FERC ${ }^{405}$

Southern Motors

Carriers Rate

Conference v. United

States 406

St. Elizabeth

Community Hosp. v.

Heckler ${ }^{407}$

Stamper v. Secretary of Agric. ${ }^{408}$

$\mathrm{x}$

$x$

$x$

$\mathbf{x}$

$x$ $x$

$x$

$\mathrm{x}$

$\mathrm{x}$

$x$

$\mathrm{x}$

$x$

$\mathrm{x}$

$\mathrm{x}$

$\mathrm{x}$

$\mathrm{x}$

$x$

$\mathrm{x}$

$x$

$\mathrm{x}$

$\mathrm{x}$

$\mathbf{x}$

$x$

$x$

$x$

$x$

396. 755 F.2d 638 (8th Cir. 1985).

397. 765 F.2d 126 (10th Cir. 1985), cert. denied, 474 U.S. 1055 (1986).

398. 747 F.2d 294 (5th Cir. 1984).

399. 749 F.2d 530 (9th Cir. 1984).

400. 775 F.2d 1028 (9th Cir. 1985).

401. 764 F.2d 135 (2d Cir. 1985).

402. 772 F.2d 1043 (2d Cir. 1985).

403. 774 F.2d 1406 (9th Cir. 1985).

404. 755 F.2d 608 (8th Cir. 1985).

405. 770 F.2d 779 (9th Cir. 1985).

406. 773 F.2d 1561 (11th Cir. 1985).

407. 745 F.2d 587 (9th Cir. 1984).

408. 722 F.2d 1483 (9th Cir. 1984). 
TABLE 4 (Continued)

\section{STATUTORY}

INTERPRETATION

Not Arg. Arg.

Arg. Lost Won

\section{PROCEDURES}

Not Arg. Arg.

Arg. Lost Won

\section{REASONS}

Not Arg. Arg.

Arg. Lost Won

Stop H-3 Ass'n v.

\section{Dole 409}

Story v. Marsh ${ }^{410}$

$x$

$\mathrm{x}$

$x$

$x$

$\mathbf{x}$

$\mathbf{x}$

Students of Cal.

School for the Blind

v. Honig 411

$\mathbf{x}$

X

$\mathbf{x}$

$\mathrm{x}$

Ins. Co. 412

Texas v. United

States $^{413}$

Texas v. United

States 414

Texas y. United

States 415

Thompson $v$.

Clark $^{416}$

Tongatapu Woodcraft

Haw., Ltd. v.

Feldman 417

Town of Burlington $v$.

Department of

Educ. ${ }^{418}$

Trailways Lines, Inc.

v. $\operatorname{ICC}^{419}$

Turner v.

Weinberger 420

U.S. Steel Corp. v.

Federal Mine Safety and Health Review Comm'n ${ }^{421}$

United States v. An

Article of Device . . .

Diapulse ${ }^{422}$

$x$

409. 740 F.2d 1442 (9th Cir. 1984), cert. denied, 471 U.S. 1108 (1985).

410. 732 F.2d 1375 (8th Cir. 1984).

411. 736 F.2d 538 (9th Cir. 1984).

412. 758 F.2d 1572 (11th Cir. 1985).

413. 730 F.2d 409 (5th Cir. 1984), cert. denied, 472 U.S. 1032 (1985).

414. 761 F.2d 211 (5th Cir. 1985).

415. 749 F.2d 1144 (5th Cir.), cert. denied, 472 U.S. 1032 (1985).

416. 741 F.2d 401 (D.C. Cir. 1984).

417. 736 F.2d 1305 (9th Cir. 1984).

418. 736 F.2d 773 (1st Cir. 1984), aff'd, 471 U.S. 359 (1985).

419. 766 F.2d 1537 (D.C. Cir. 1985).

420. 728 F.2d 751 (5th Cir. 1984).

421. 756 F.2d 658 (8th Cir. 1985).

422. 768 F.2d 826 (7th Cir. 1985). 
TABLE 4 (Continued)

\section{STATUTORY}

INTERPRETATION

Not Arg. Arg.

Arg. Lost Won
PROCEDURES

Not Arg. Arg. Not Arg. Arg.

Arg. Lost Won Arg. Lost Won

United States v.

Garner ${ }^{423}$

$\mathrm{x}$

$\mathbf{x}$

Bernard Parish 424

United Airlines, Inc.

v. $\mathrm{CAB}^{425}$

Veterans Admin.

Medical Center v.

Federal Labor

Relations Auth. ${ }^{426}$

Virginia Agric.

Growers Ass'n v.

Donovan 427

Walker v. Navajo-

Hopi Indian

Relocation

Comm'n ${ }^{428}$

Wold

Communications, Inc.

v. FCC $^{429}$

Woodard v. United

States ${ }^{430}$

Wright Memorial

Hosp. v. NLRB ${ }^{431}$

Yaffe Iron and Metal

Co. v. EPA ${ }^{432}$ $\mathbf{x}$

$\mathbf{x}$

$\mathbf{x}$

$x$

$\mathbf{x}$

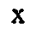

$x$

$\mathbf{x}$

$\mathrm{x}$

$\mathbf{x}$

$\mathrm{x}$ $\mathbf{x}$

$\mathbf{x}$

$\mathrm{x}$

$\mathbf{x}$

$\mathbf{x}$

$x$

$\begin{array}{lll} & \mathbf{x} & \mathrm{x} \\ \mathrm{x} & \mathrm{x} & \mathrm{x} \\ \mathrm{x} & \mathrm{x} & \mathrm{x} \\ \mathrm{x} & \mathrm{x} & \mathrm{x}\end{array}$

\footnotetext{
423. 767 F.2d 104 (5th Cir. 1985).

424. 756 F.2d 1116 (5th Cir. 1985), cert. denied, 474 U.S. 1070 (1986).

425. 766 F.2d 1107 (7th Cir. 1985).

426. 732 F.2d 1128 (2d Cir. 1984).

427. 774 F.2d 89 (4th Cir. 1985).

428. 728 F.2d 1276 (9th Cir.), cert. denied, 469 U.S. 918 (1984).

429. 735 F.2d 1465 (D.C. Cir. 1984).

430. 725 F.2d 1072 (6th Cir. 1984).

431. 771 F.2d 400 (8th Cir. 1985).

432. 774 F.2d 1008 (10th Cir. 1985).
} 